\title{
Mechanistic Insights of Chelator Complexes with Essential Transition Metals: Antioxidant/Pro-Oxidant Activity and Applications in Medicine
}

\author{
Viktor A. Timoshnikov ${ }^{1, *(\mathbb{D})}$, Olga Yu. Selyutina ${ }^{1}\left(\mathbb{D}\right.$, Nikolay E. Polyakov $^{1}\left(\mathbb{D}\right.$, Victoria Didichenko ${ }^{2}$ \\ and George J. Kontoghiorghes $2, * \mathbb{D}$ \\ 1 Institute of Chemical Kinetics \& Combustion, 630090 Novosibirsk, Russia; \\ olga.gluschenko@gmail.com (O.Y.S.); polyakov@kinetics.nsc.ru (N.E.P.) \\ 2 Postgraduate Research Institute of Science, Technology, Environment and Medicine, Limassol 3021, Cyprus; \\ vicdidichenko@outlook.com \\ * Correspondence: timoshnikov@kinetics.nsc.ru (V.A.T.); kontoghiorghes.g.j@pri.ac.cy (G.J.K.)
}

Citation: Timoshnikov, V.A.;

Selyutina, O.Y.; Polyakov, N.E.;

Didichenko, V.; Kontoghiorghes, G.J.

Mechanistic Insights of Chelator

Complexes with Essential Transition

Metals: Antioxidant/Pro-Oxidant

Activity and Applications in

Medicine. Int. J. Mol. Sci. 2022, 23,

1247. https://doi.org/10.3390/

ijms23031247

Academic Editor: Guido R. M. M.

Haenen

Received: 29 December 2021

Accepted: 20 January 2022

Published: 23 January 2022

Publisher's Note: MDPI stays neutral with regard to jurisdictional claims in published maps and institutional affiliations.

Copyright: (C) 2022 by the authors. Licensee MDPI, Basel, Switzerland. This article is an open access article distributed under the terms and conditions of the Creative Commons Attribution (CC BY) license (https:// creativecommons.org/licenses/by/ $4.0 /)$.

\begin{abstract}
The antioxidant/pro-oxidant activity of drugs and dietary molecules and their role in the maintenance of redox homeostasis, as well as the implications in health and different diseases, have not yet been fully evaluated. In particular, the redox activity and other interactions of drugs with essential redox metal ions, such as iron and copper, need further investigation. These metal ions are ubiquitous in human nutrition but also widely found in dietary supplements and appear to exert major effects on redox homeostasis in health, but also on many diseases of free radical pathology. In this context, the redox mechanistic insights of mainly three prototype groups of drugs, namely alpha-ketohydroxypyridines (alpha-hydroxypyridones), e.g., deferiprone, anthraquinones, e.g., doxorubicin and thiosemicarbazones, e.g., triapine and their metal complexes were examined; details of the mechanisms of their redox activity were reviewed, with emphasis on the biological implications and potential clinical applications, including anticancer activity. Furthermore, the redox properties of these three classes of chelators were compared to those of the iron chelating drugs and also to vitamin $C$, with an emphasis on their potential clinical interactions and future clinical application prospects in cancer, neurodegenerative and other diseases.
\end{abstract}

Keywords: chelators; transition metals; reactive oxygen species; antioxidant activity; pro-oxidant activity; alpha-ketohydroxypyridines; hydroxypyridones; anthraquinones; thiosemicarbazones; ascorbic acid

\section{Introduction}

There is an increased interest for the study of free radical reactions in biological systems and their role in health and disease, which has continued for more than 40 years [1-5]. Redox activity is also of interest in many areas of medicine, such as pharmacology, toxicology and metabolism and also in many biological processes, including energy transduction and the circadian rhythm [1-8]. Furthermore, in each year new, free radical mechanisms are discovered, and the schemes of metabolic pathways involving free radicals are supplemented and increase in numbers. For example, there is an increased interest following the discovery of a new mechanism of programmed cell death involving iron called ferroptosis [7-13]. However, despite increased research activity in this direction, all radical processes occurring within the cell during ferroptosis have not yet been fully investigated or clarified [14,15]. Nevertheless, the data obtained so far on ferroptosis allowed a new look at the pathogenesis of various diseases, including Alzheimer's disease, atherosclerosis, cancer, etc. [15-17]. It should be noted that in all of the above pathologies and the overwhelming majority of other free radical processes, transition metal ions and especially iron and copper, play a very important role. Under normal conditions, the catalytic oxidative 
function of these transition metal ions is balanced by natural antioxidant mechanisms. However, due to various exogenous and endogenous factors, the redox balance can be disturbed, which leads to the uncontrolled generation of free radicals including reactive oxygen species (ROS) [18-20].

One of the earliest and most commonly used methods of treating metal-dependent pathologies was the use of chelating drugs, e.g., deferiprone (L1), deferasirox and deferoxamine, in iron overloading conditions, where a chelator can bind to metal ions and remove or displace them from the site of toxicity [3,21-24]. However, it was also found that other chelators with increased lipophilicity and other specific chelating properties can bind to transition metals, increase ROS and cause cancer cell damage, with high potential for development as anticancer drugs, e.g., omadine and triapine [25-28]. In this context and following the increased interest in the field of free radical processes, the number of publications devoted to the synthesis and development of new chelating agents and their effect on redox processes in the human body and new possible applications in medicine has grown.

In this review we will examine the effects of three main chelator groups namely the alpha-ketohydroxypyridines (KHP) or alpha-hydroxypyridones, anthraquinones, and thiosemicarbazones (TSCs), which have different redox properties. Despite the fact that these compounds and their chelating activity were discovered back in the 20th century, interest in them has not subsided to this day [29-31]. New chelating agents are being synthesized and the possibility of their application in various fields of medicine, including redox activity and other properties are being actively investigated. It should be noted that this review focuses on the physicochemical properties of chelators, their redox activity, the effect on the redox properties of their metal complexes, as well as their potential therapeutic use. In addition, the role of vitamin C, a natural antioxidant/chelator in the generation and inhibition of ROS with the participation of chelate complexes of transition metals will also be discussed.

\section{The Role of Essential Transition Metals in Living Systems}

The most common transition metals in living systems are iron and copper. The regulation of the absorption, transport, storage and utilization of iron in humans is primarily controlled by a number of specific regulatory proteins and transcription factors, for example hemoglobin, transferrin, ferritin, ribonucleotide reductase, etc. As with other ions of essential metals, under normal conditions, iron has a specific metabolic pathway, biomolecular sites of interaction, specific tissue deposition and storage, and specific transport routes in blood and cells, as well as excretion. Most of the iron that has entered the cytoplasm of the cell (labile iron pool) is used for the synthesis of hemoglobin in erythroid cells, whereas, in non-erythroid cells, for the synthesis of DNA, RNA, and iron-containing enzymes. The remaining part of iron is stored intracellularly in a safe, polynuclear and non-toxic form in the protein ferritin [32-35].

Iron metabolic imbalances are commonly associated with a number of serious conditions, such as iron deficiency anemia, which affects between a third and a quarter of the world's population [36]. In contrast, many hundred thousands of patients with chronic hematological and malignant diseases, including thalassemia, sickle cell anemia, hematopoietic stem cell transplantation, aplastic anemia and cancer, suffer from iron overload due to multiple blood transfusions for the treatment of refractory anemia [37-39]. Likewise, iron overload caused by increased absorption of dietary iron in the gastrointestinal tract in the inherited disorder of idiopathic hemochromatosis affects millions of people $[40,41]$.

Copper also plays an important role in the biology of living organisms. This element is widely used by cells in which it can perform regulatory and catalytic functions [42,43]. Many enzymes are associated with copper, for example, ascorbate oxidase, cytochrome oxidase, tyrosinase, superoxide dismutase, dopamine hydroxylase, etc. [44-47].

Under normal physiological conditions, the level of copper in the body is well regulated by metabolic mechanisms. However, there are many diseases associated with copper 
imbalance and toxicity, such as Mencke's and Wilson's diseases. In the case of Wilson's disease, dietary copper absorption increases which leads to its accumulation, mainly in the liver, leading to cirrhosis. Copper accumulation is also observed in the brain, kidneys and cornea, causing damage and dysfunction of these organs [48].

The main reason for the negative effect of iron and copper is their participation in oxidation-reduction (redox) reactions, as a result of which ROS are generated and produced without control. Reactive oxygen species are capable of oxidizing and damaging almost all biomolecules including lipids, sugars, amino and nucleic acids [2,4,49]. Usually, the body can cope with oxidative stress using natural antioxidants, for example alpha-tocopherol (vitamin E), ascorbic acid (vitamin C), glutathione, superoxide dismutases (SODs), etc., which are able to trapping various ROS [50-52]. However, in the case of a number of diseases, the body is unable to inhibit the uncontrolled generation of ROS.

It is believed that the main mechanism of iron and copper toxicity is their ability to participate in Fenton-like reactions leading to the formation of ROS, including highly toxic hydroxyl radicals $\left({ }^{\circ} \mathrm{OH}\right)$ [53-55]. The mechanism of radical generation by iron and copper has been studied in detail by various physical methods, including EPR with spin traps, and is described in detail in the literature and the reaction Equations (1)-(5) [56-59].

$$
\begin{gathered}
\mathrm{Cu}^{2+}+\mathrm{H}_{2} \mathrm{O}_{2} \stackrel{\mathrm{k}_{1}=460 \mathrm{M}^{-1} \mathrm{~s}^{-1}}{\longrightarrow} \mathrm{Cu}^{+}+2 \mathrm{H}^{+}+\dot{\mathrm{O}}_{2}^{-} \\
\mathrm{Cu}^{+}+\mathrm{H}_{2} \mathrm{O}_{2} \stackrel{\mathrm{k}_{2}=<100 \mathrm{M}^{-1} \mathrm{~s}^{-1}}{\longrightarrow} \mathrm{Cu}^{2+}+\mathrm{OH}+\mathrm{OH}^{-} \\
\mathrm{Fe}^{2+}+\mathrm{H}_{2} \mathrm{O}_{2} \stackrel{\mathrm{k}_{3}=63 \mathrm{M}^{-1} \mathrm{~s}^{-1}}{\longrightarrow} \mathrm{Fe}^{3+}+\mathrm{OH}+\mathrm{OH}^{-} \\
\mathrm{Fe}^{3+}+\mathrm{H}_{2} \mathrm{O}_{2} \stackrel{\mathrm{K}=3.1 \times 10^{-3}}{\longrightarrow}\left[\mathrm{Fe}^{3+}\left(\mathrm{HO}_{2}\right)\right]^{2+}+\mathrm{H}^{+} \\
{\left[\mathrm{Fe}^{3+}\left(\mathrm{HO}_{2}\right)\right]^{2+} \stackrel{\mathrm{k}_{4}=2.7 \times 10^{-3} \mathrm{~s}^{-1}}{\longrightarrow} \mathrm{Fe}^{2+}+\mathrm{HO}_{2}}
\end{gathered}
$$

The rate of reaction Equation (2) can vary significantly $\left(\sim 100-10,000 \mathrm{M}^{-1} \mathrm{~s}^{-1}\right)$ depending on the temperature, ionic strength, $\mathrm{pH}$, and oxygen content of the solution. This reaction is described in more detail in [59].

However, there is no consensus on the mechanism of the Fenton reaction with the participation of copper ions $[56,60,61]$. Some of the authors suggest that there are intermediate reactions with the formation of the $\mathrm{Cu}$ (III) ion as an intermediate product of reaction Equations (6)-(8), as well as the formation of hydroxyl radicals as the final product of these reactions $[56,57]$. There are also different opinions about the reaction rate constant regarding Equation (1).

$$
\begin{gathered}
\mathrm{Cu}^{+}+\mathrm{H}_{2} \mathrm{O}_{2} \stackrel{\mathrm{k}_{5}=61 \mathrm{M}^{-1} \mathrm{~s}^{-1}}{\longrightarrow} \mathrm{Cu}^{3+}+2 \mathrm{OH}^{-} \\
\mathrm{Cu}^{3+}+\mathrm{Cu}^{+} \stackrel{\mathrm{k}_{6}=3.5 \times 10^{9} \mathrm{M}^{-1} \mathrm{~s}^{-1}}{\longrightarrow} 2 \mathrm{Cu}^{2+} \\
\mathrm{Cu}^{3+}+\mathrm{H}_{2} \mathrm{O}_{2} \stackrel{\mathrm{k}_{7} \leq 1.3 \times 10^{5} \mathrm{M}^{-1} \mathrm{~s}^{-1}}{\longrightarrow} \mathrm{Cu}^{2+}+2 \mathrm{H}^{+}+\dot{\mathrm{O}}_{2}^{-}
\end{gathered}
$$

Reactive oxygen species formed during the Fenton reaction can initiate more complex biochemical chain reactions, for example, the peroxidation of lipids that are components of cell membranes. In particular, the recently discovered mechanism of programmed cell death ferroptosis is based on lipid peroxidation of the cell membranes with the participation of iron ions, which leads to disruption of homeostasis, destruction of the cell membrane and ultimately cell death $[62,63]$. However, despite the enormous interest from the scientific community, the detailed mechanism of this reaction has not been fully understood due to the complexity of the system and the short lifetime of the intermediates formed in the course of the redox reactions [64]. 


\section{The Potential Antioxidant/Pro-Oxidant Effects of Ascorbic Acid}

Ascorbic acid $\left(\mathrm{AscH}_{2}\right)$ is one of the main vitamins which is not synthesized in human and other primate organisms. This compound is extremely important for the normal functioning of the body and is found in many vegetables and fruits. Ascorbic acid is mainly found in acidic conditions, while at neutral $\mathrm{pH}$ it is in the form of the ascorbate anion $\left(\mathrm{AscH}^{-}\right)$. Under certain conditions $\mathrm{AscH}_{2}$ is capable of oxidizing, transforming first into the ascorbyl radical $\left(\mathrm{AscH}^{\bullet}\right)$, and then into the dehydroascorbate (DHA) (Figure 1). In addition to its nutritional value, ascorbic acid has wide medical applications, including the treatment of vitamin $C$ deficiency, pneumonia, acute respiratory failure, multiple myeloma, metastatic colorectal carcinoma, metastatic melanoma, coronary heart disease, type 2 diabetes, dementia, Alzheimer's disease and COVID 19 [65-74]. Ascorbic acid has a number of physicochemical and biological functions, including antioxidant, chelating, and coenzyme activities [75-77].
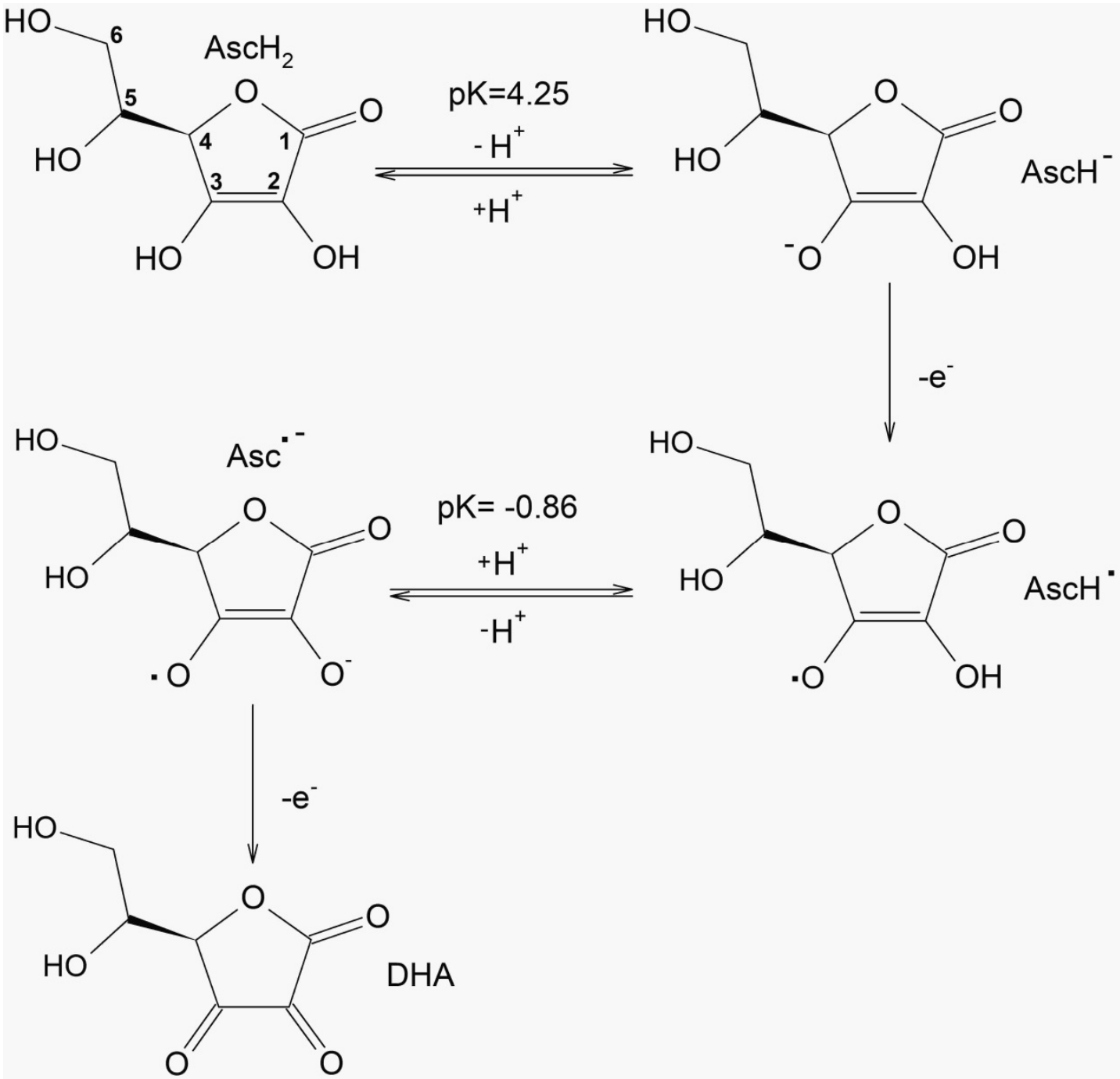

Figure 1. The structure of ascorbic acid $\left(\mathrm{AscH}_{2}\right)$ and its scheme of oxidation with the main products of redox reactions namely ascorbate anion $\left(\mathrm{AscH}^{-}\right)$, ascorbyl radical $\left(\mathrm{AscH}{ }^{\bullet}\right)$, ascorbyl anion radical $\left(\mathrm{Asc}^{\bullet-}\right)$ and dehydroascorbic acid (DHA).

Moreover, ascorbate is also involved in tissue repair, the production of neurotransmitters and is also important for the immune system. The main function of ascorbic acid is its 
antioxidant activity through its ability to interact with composite radicals, restoring them as shown in the Equation (9):

$$
\mathrm{AscH}_{2}\left(\text { or } \mathrm{AscH}^{-}\right)+\dot{\mathrm{R}} \rightarrow \dot{\mathrm{Asc}}\left(\text { or } \dot{\mathrm{Asc}}{ }^{-}\right)+\mathrm{RH}
$$

where $\dot{R}$ is the free radical (see Table 1 ).

Table 1. Rate constants of the reaction of free radicals with ascorbic acid at pH 7.4.

\begin{tabular}{cc}
\hline Radical & $\mathbf{k}\left(\mathbf{M}^{-\mathbf{1}} \mathbf{s}^{\mathbf{- 1}}\right)$ \\
\hline$\bullet$ OH (hydroxyl) & $1.1 \times 10^{10}$ \\
$\mathrm{RO}^{\bullet}($ tert-butyl alkoxyl radical) & $1.6 \times 10^{9}$ \\
$\mathrm{ROO}^{\bullet}\left(\right.$ alkyl peroxyl radical, e.g., $\left.\mathrm{CH}_{3} \mathrm{OO}^{\bullet}\right)$ & $1-2 \times 10^{6}$ \\
$\mathrm{GS}^{\bullet}($ glutathiol radical) & $6 \times 10^{8}$ \\
$\mathrm{TO}^{\bullet}($ tocopheroxyl radical) & $2 \times 10^{5}$ \\
$\mathrm{Asc}^{\bullet-}($ dismutation) & $2 \times 10^{5}$ \\
$\mathrm{O}_{2}{ }^{\bullet-} /{ }^{\bullet} \mathrm{OOH}$ & $1 \times 10^{5}$ \\
\hline
\end{tabular}

As a powerful water-soluble antioxidant, ascorbic acid provides effective protection to cell membranes, proteins and other biomolecules from oxidation by many oxidants, including superoxide radical $\left(\mathrm{O}_{2}^{\bullet-}\right)$, hydrogen peroxide $\left(\mathrm{H}_{2} \mathrm{O}_{2}\right), \bullet \mathrm{OH}$, peroxyl radical $\left({ }^{\bullet} \mathrm{OOH}\right)$ and singlet oxygen $\left({ }^{1} \mathrm{O}_{2}\right)[2,4,78-80]$. As a result of the redox reaction, a stable radical $\mathrm{AscH}^{\bullet}$ is formed. However, under physiological conditions, this radical is deprotonated ( $\mathrm{pKa}-0.86)$, transforming into the $\mathrm{Asc}^{\bullet-}$ radical. The rate constants of the reactions with the most common radicals were previously calculated as shown in Table 1 [81].

In addition to antioxidant activity, ascorbic acid can also exhibit pro-oxidant activity [82-89]. It can react with oxidized transition metal ions such as $\mathrm{Fe}^{3+}$ and $\mathrm{Cu}^{2+}$, causing their reduction Equations (10) and (11):

$$
\begin{aligned}
& \mathrm{Fe}^{3+}+\mathrm{AscH}_{2}\left(\text { or } \mathrm{AscH}^{-}\right) \rightarrow \mathrm{Fe}^{2+}+\mathrm{AscH}\left(\text { or } \mathrm{Asc}^{-}\right)+\mathrm{H}^{+} \\
& \mathrm{Cu}^{2+}+\mathrm{AscH}_{2}\left(\text { or } \mathrm{AscH}^{-}\right) \rightarrow \mathrm{Cu}^{+}+\mathrm{AscH}\left(\text { or } \mathrm{Asc}^{-}\right)+\mathrm{H}^{+}
\end{aligned}
$$

Further, the reduced metal ions are able to participate in the Fenton reaction Equations (2) and (3). Thus, the reactions of ascorbic acid with $\mathrm{Fe}^{3+}$ and $\mathrm{Cu}^{2+}$ ions are an additional channel for the formation of ROS. As a result, there is a significant increase in the rate of oxidation of various compounds, including many biomolecules [89-92]. In general, there is a debate in the medical community about the use of ultrahigh doses of ascorbic acid for the treatment of cancer in combination with other anticancer agents [93-98].

It should be mentioned that ascorbic acid is capable of chelating various metals. There are many studies on the influence of its metal coordination properties on important biological redox processes [99-103]. The equilibrium constants of ascorbic acid metal complexes are low in comparison with various chelating drugs used to treat diseases associated with metal overload [104,105]. The main chelate center of ascorbic acid is considered to be $\mathrm{O}(2)$ and $\mathrm{O}(3)$ nuclei, which are capable of forming non-covalent donoracceptor bonds with a metal ion after deprotonation of the $\mathrm{OH}$ groups [99]. There are many studies of chelating complexes of ascorbic acid with iron and copper ions. Complexes with $\mathrm{Fe}^{3+}$ and $\mathrm{Cu}^{2+}$ ions are unstable and decompose due to intramolecular electron transfer within a few milliseconds with the formation of oxidation products such as DHA and $\mathrm{Cu}^{+}$and $\mathrm{Fe}^{2+}$ ions [106-108]. In turn, the complexes of ascorbic acid with the $\mathrm{Fe}^{2+}$ ion are fairly stable, with stoichiometry 2:1 $\left[\mathrm{Asc}_{2} \mathrm{Fe}^{2+}\right.$ ] [99]. As for $\mathrm{Cu}^{+}$, these complexes are unstable in aqueous solutions due to the high reactivity with ions, which can be oxidized to $\mathrm{Cu}^{2+}[107,109]$.

Despite that ascorbic acid has a relatively low affinity for metals, it can interact with other chelate complexes, affecting their redox activity and can cause either an increase or 
a decrease in the production of ROS. The main mechanisms of action are the reactions of electron transfer between the chelator and ascorbic acid, as well as the incorporation of ascorbate into the internal coordination sphere of the complex [74,110-113]. More details of the effects of ascorbic acid on the redox activity of chelators are discussed below.

\section{Redox Properties and Biological Implications of Chelating Drugs}

The major use of chelating drugs is the treatment of diseases associated with metal overload. These drugs are able to bind to metal ions and remove them from the body. The main requirements for clinical use of these chelators are mainly high affinity for a particular metal, bioavailability, high stability constants of the complexes and low toxicity. An important aspect of toxicity is that the resulting chelator metal complexes should not participate in redox reactions with the formation of increased ROS.

There are two main actions of chelators that can reduce oxidative stress caused by metal ions, namely the decrease in the redox potential (energetic) and binding to vacant coordination sites of a metal ion (dimensional) [114]. Another aspect of toxicity is the photostability of chelators and their metal complexes upon the formation of chelate complexes, with photosensitivity of the drug being an important parameter considered in clinical use. In this context, under the action of radiation, the chelator and/or metal is able to participate in redox reactions with the formation of ROS or toxic products [2,4,49].

One of the most effective groups of iron chelators is the alpha-ketohydroxypyridines (KHP) or alpha-hydroxypyridones [115-122]. About 100 KHP have been synthesized including bidentate, tetradentate and hexadentate chelators, which have been screened in vitro, in vivo and also some in clinical trials for clinical use in the treatment of iron overload and other diseases $[22,23,118,122-127]$. There are three prototype structures the 3-hydroxypyrid-4-ones (I). 3-hydroxypyrid-2-ones (II) and 1-hydroxypyrid-2-ones (III). In each case the iron binding site comprises of an oxygen atom $(\mathrm{O})$ and adjacent hydroxyl $(-\mathrm{OH})$ group (Figure 2$)$.

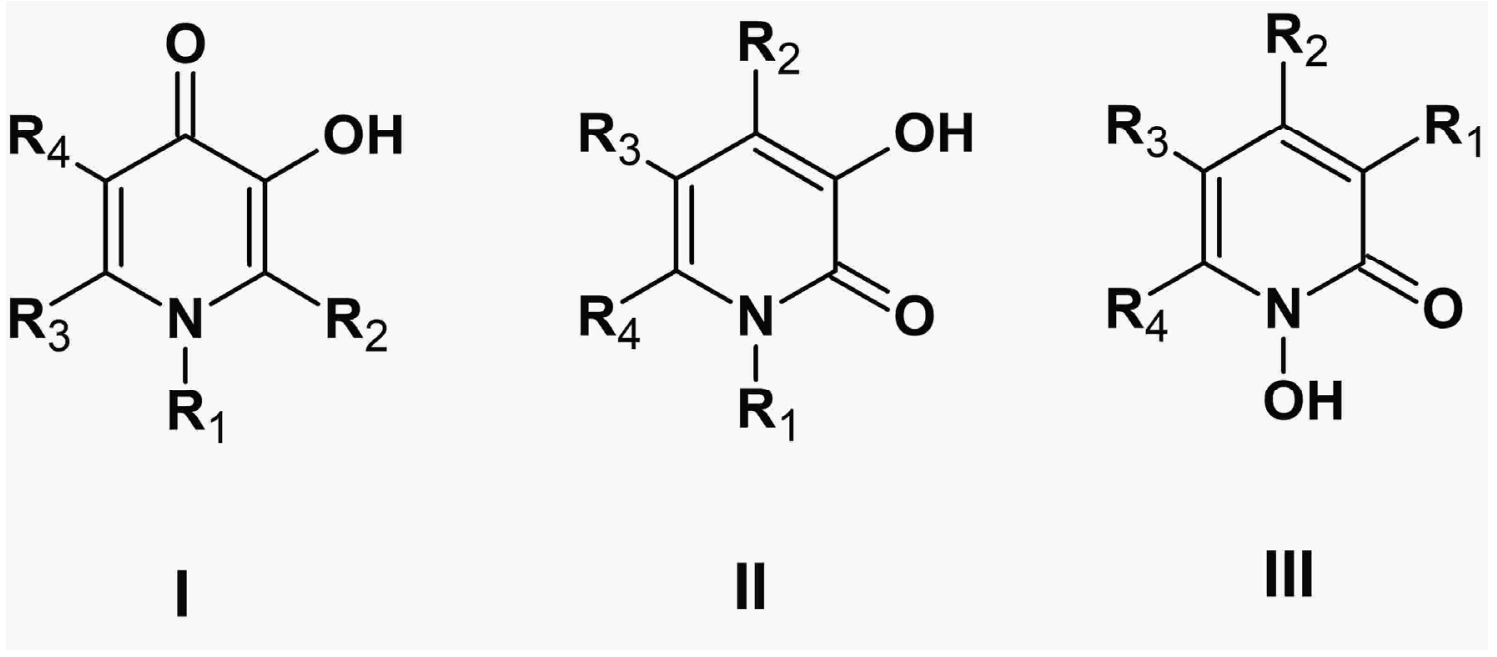

Figure 2. Chemical structures of alpha-ketohydroxypyridine chelators.

In addition to treating diseases associated with metal overload in the body, chelators are also used to treat cancer. There are many approaches to potential cancer treatment using chelators including photodynamic therapy and chemotherapy $[128,129]$. The chelators with anticancer activity can be divided into many categories including two main group categories according to the type of effect on the cancer cell. In one category, the effect is related to molecular insertion into DNA, thereby inhibiting the replication and repair of genetic material and the second is participation in redox reactions with the formation of ROS, which in turn oxidize and destroy DNA, proteins, and lipid membranes [130-134]. 
There are many other groups of chelators with potential anticancer activity with different chemical structures not related to KHP. Among the most promising chelating groups of anticancer agents are the anthraquinones and TSCs (Figure 3). Nevertheless, the anticancer drug members with metal chelating potential of these two groups have a number of toxic side effects, similar to any other drug, including low selectivity for cancer cells, cardiotoxicity, hair follicle toxicity, etc. $[135,136]$.

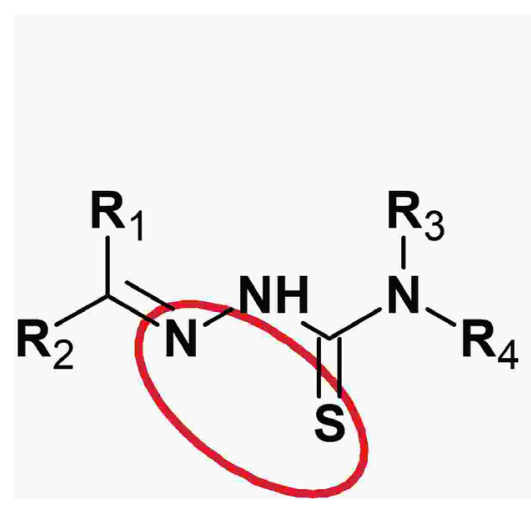<smiles>[R6]c1c([R6])c([R5])c2c(c1[R6])C(=O)c1c([R2])c([R5])c([R2])c([R2])c1C2=O</smiles>

Figure 3. Chemical structures of thiosemicarbazones and anthraquinone-like anticancer drugs with chelating potential. The red circle marks the chelating centers of the molecules. $R_{n}$ denotes various substituents.

In general, chelatting drugs have different physicochemical properties that affect the course of redox reactions associated with transition metal ions. In this context, at least three separate redox related mechanisms can be distinguished, namely the ability of the chelator to participate in redox reactions, a change in the redox (electrode) potential of a complexed metal, and the creation/reservation of coordination binding site of complexed metal (Scheme 1).

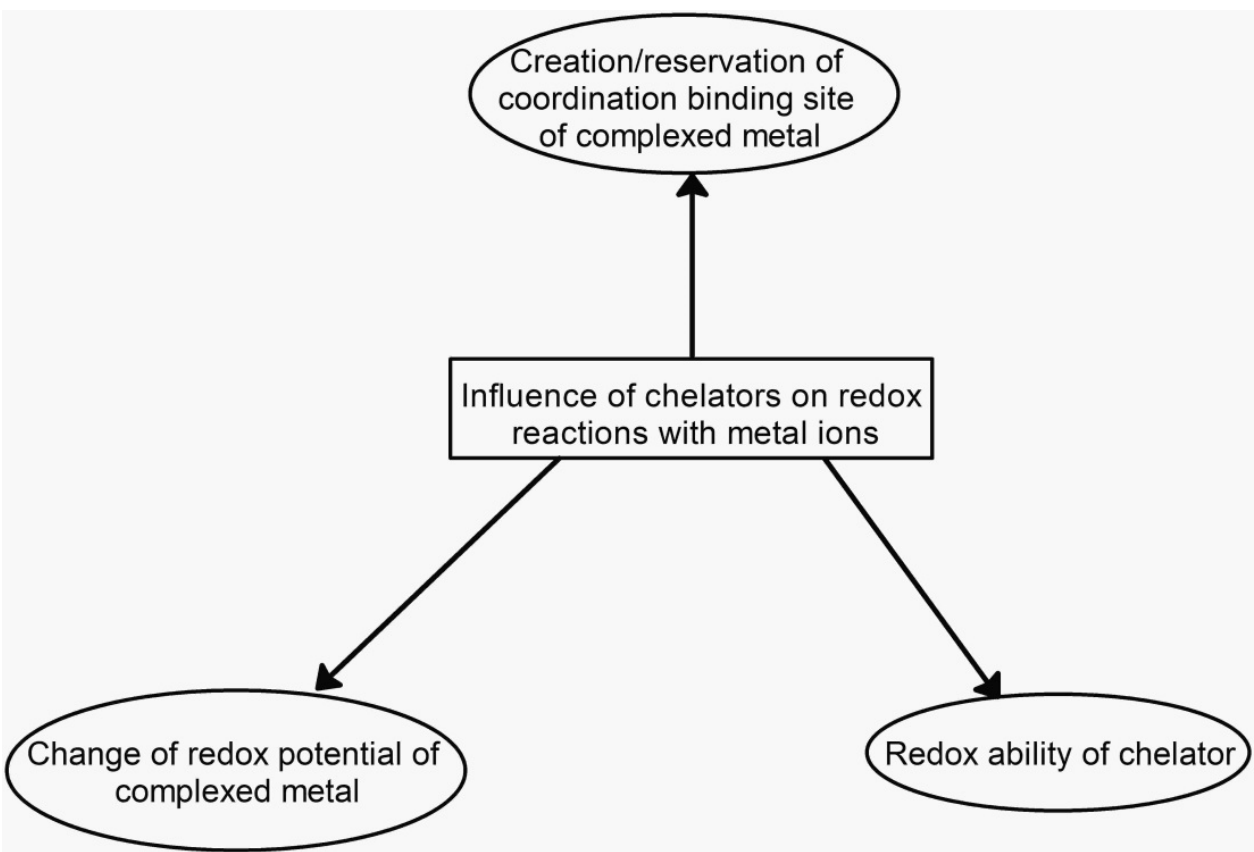

Scheme 1. Influence of chelators on redox reactions with metal ions.

It should be noted that some chelators can participate in redox reactions with the formation of ROS in the absence of metal ions. For example, most of the biomolecules in biological systems such as DNA, protein and lipids are electron donors and chelators 
with electron acceptor properties, which are able to enter into dark and photoinduced chemical reactions, forming ROS [2,4,49]. Among such chelators, anthraquinones can be distinguished, since they have not only electron acceptor properties, but are also capable of participating in redox reactions with complexed transition metal ions, such as iron and copper, transforming them into a more reactive state, thereby inducing the Fenton reaction Equations (1)-(8) [137]. However, some other chelators can act as radical scavengers due to certain chemical groups, e.g., $-\mathrm{OH}$ in the structure of the molecule. An example are phenol-containing compounds where the hydroxyl group is capable of trapping various $\operatorname{ROS}[138,139]$.

Another mechanism of chelators that affects the redox activity of complexed metals is the change of the redox (electrode) potential of a metal ion. It is known that metalchelate is an effective catalyst for redox reactions if its potential lies in the range between $\mathrm{E}^{0}\left(\mathrm{O}_{2} / \mathrm{O}_{2}^{\bullet-}\right),-0.33 \mathrm{~V}$ and $\mathrm{E}^{0^{\prime}}\left(\mathrm{H}_{2} \mathrm{O}_{2}, \mathrm{H}^{+} / \mathrm{HO}^{\bullet}, \mathrm{H}_{2} \mathrm{O}\right),+0.39 \mathrm{~V}[86,140]$. Thus, if the electrode potential of the complexed metal is below $-0.33 \mathrm{~V}$, then the redox reaction will be energetically unfavorable. However, if the electrode potential is above $+0.39 \mathrm{~V}$, then the rate of redox reactions becomes diffusion controlled. In this regard, after several cycles of reactions, the redox activity of the chelate complexes decreases and the concentration of potential electron donors/acceptors in the local environment of metal-chelate also decreases [86,140]. Therefore, metal-chelate with an electrode potential ranging from $-0.33 \mathrm{~V}$ to $+0.39 \mathrm{~V}$ will be the most effective redox active agents.

A third mechanism influencing the redox activity of complexed metals is the creation/reservation of a coordination binding site of the complexed metal. In this case, this implies the possibility of adding hydrogen peroxide $\left(\mathrm{H}_{2} \mathrm{O}_{2}\right)$ or another ligand to the internal coordination sphere of the complex with further formation of various ROS [86,114]. This mechanism depends on many factors, including the coordination number of the complexed metal, the density of the chelator, the number of ligands in the internal coordination sphere, the stability constants of the complex, the charge of the internal coordination sphere, $\mathrm{pH}$ etc. These factors cannot be considered separately, because they are interrelated with each other and affect the reactivity of the complexed metal ion.

Overall, it can be suggested that the effect of a chelator on the redox activity of a complexed metal ion is a multifactorial system consisting of several mechanisms. These mechanisms could be analyzed in detail using several groups of chelators, including the $\mathrm{KHP}$, anthraquinones, and TSCs, and the possible applications and other implications in medicine.

\section{Alpha-Ketohydroxypyridine Chelators}

The alpha-ketohydroxypyridine (KHP) or alpha-hydroxypyridinone class of chelators has been designed and actively studied since the 1980s, leading to the discovery of L1 (Figure 4) [21-23,118-127,141]. This impetus served to develop a therapeutic direction associated with the treatment of diseases caused by an excess of metals in the body. Most of the KHP synthesized are bidentate chelators with an oxygen atom $(\mathrm{O})$ and adjacent hydroxyl $(-\mathrm{OH})$ group at the metal binding site with the two oxygen molecules as the electron donors for bond formation with metal ions. The great interest in this group of chelators stems from the high affinity/binding constant of iron and other metal ions, as well as low toxicity [116,118-122,142].

There are many potential applications in the use of KHP and their metal complexes in biology and medicine, including the treatment of diseases associated with excess of iron and other metal deposition, e.g., neurodegenerative diseases or iron metabolic imbalance [143-145]. The effect of KHP chelators on the redox activity of metals is of pharmacological and toxicological importance in all these diseases. In the case of iron and copper overloading diseases, KHP are required to possess antioxidant activity in order to reduce the oxidative stress caused by the uncontrolled generation of ROS in reactions involving transition metal ions as shown in the reaction Equations (1)-(8). 


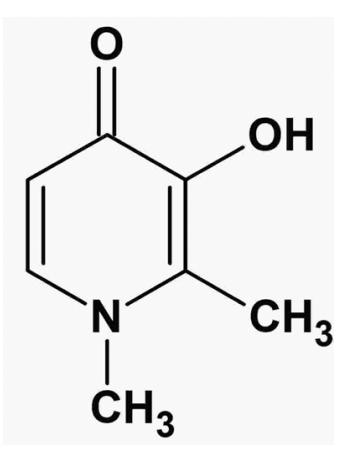

Figure 4. Chemical structure of deferiprone (L1). The alpha-ketohydroxy metal binding site of L1 comprises of an oxygen atom $(\mathrm{O})$ and adjacent hydroxyl $(-\mathrm{OH})$ group.

Despite more than 30 years of development of pharmacological research in chelation therapy for the treatment of iron overload diseases, L1 remains one of the leading effective drugs for the treatment of such diseases. The reason for the effectiveness of this drug lies in several factors, including high affinity for iron ions, low redox activity of iron chelate complexes and also, high solubility and bioavailability [118,120,144-146].

Previous studies have shown that L1 has a stronger affinity (stability constant, $\log \beta$ ), for $\mathrm{Fe}^{3+}$ (35.0), as well as to $\mathrm{Cu}^{2+}$ (19.6), than to other essential metals, such as $\mathrm{Zn}^{2+}(13.5)$. This illustrates the selectivity of L1 in relation to iron in comparison to the binding of other transition metal ions [105,118,146].

A major factor related to the toxicity of chelating drugs is the low redox activity of their metal complexes $[3,147]$. This property has been confirmed by both physicochemical studies in vitro, including the study of the electrode potential of chelate complexes of L1 using in electron paramagnetic resonance (EPR), nuclear magnetic resonance (NMR) and chemically induced dynamic nuclear polarization (CIDNP) and also the effect of its complexes with iron and copper ions in dark and photoinduced reactions, as well as in other in vivo studies [88,89,148-151]. In particular, it was shown that L1 inhibits the Fenton reaction with iron and copper ions as shown in Equations (1)-(8), reducing the yield of hydroxyl radicals to negligible or almost zero levels $[88,147,148]$. In addition, NMR studies of the effect of L1 on the peroxidation of linoleic acid (LA) micelles with the participation of iron and copper ions were also carried out. The results have shown that L1 is able to slow down the LA peroxidation reaction by more than 1000 times, which indicates a high antioxidant activity as a chelator used to treat diseases associated with an excess or catalytic iron in the body $[88,89,147]$. Furthermore, L1 has also shown antioxidant activity in the photochemical decomposition of iron aqua complexes with the formation of hydroxyl radicals [148]. In the case of therapeutic use for the treatment of patients with $\beta$-thalassemia, L1 also showed itself as a drug that reduces oxidative stress and restores the functions of different organs and tissues [151].

One of the main reasons for the redox inactivity of chelate complexes L1 is the low level of the electrode potential $\left(-0.62 \mathrm{~V}\right.$ for $\left.\mathrm{Fe}^{3+} / \mathrm{Fe}^{2+} \mathrm{L}_{3}\right)[86,150]$. An additional factor influencing the antioxidant activity of L1 is the complete binding of iron and copper. As a bidentate chelator, L1 forms complexes with $\mathrm{Fe}^{3+}$ and $\mathrm{Cu}^{2+}$ with stoichiometry of 3:1 and $2: 1$, respectively, under physiological conditions $[118,146,152,153]$. Therefore, it is difficult for various oxidizing ligands, such as $\mathrm{H}_{2} \mathrm{O}_{2}$, to integrate into the internal coordination sphere for further oxidation reactions with a complexed metal ion.

Many other properties and characteristics contribute to the high efficiency of L1 as a therapeutic agent for the treatment of different diseases. These include the neutral charge of L1 and its iron complex at physiological $\mathrm{pH}$, high solubility in water, hydrophilicity (partition coefficient n-octanol/water 0.19), high bioavailability, rapid gastrointestinal absorption (0.7-32 $\mathrm{min}$ ) and elimination time of chelate complexes with iron ions (47-134 min) [105,118,154,155]. 
The influence of ascorbic acid on the redox activity of L1 at different concentrations was also investigated by EPR, NMR and UV-visible spectroscopy. It was found that, when the concentration of L1: $\mathrm{Fe}^{3+}$ is less than 2:1, ascorbic acid exhibits pro-oxidant effects and increases the production of ${ }^{\bullet} \mathrm{OH}$ in the Fenton reaction Equations (1)-(8). However, at higher concentrations of L1, ascorbic acid exhibits antioxidant activity and decreases the level of ${ }^{\bullet} \mathrm{OH}$ production. This phenomenon is explained by the incorporation of $\mathrm{AscH}_{2}$ into the inner sphere of the chelate complex $\left[\mathrm{L1}_{3} \mathrm{Fe}^{3+}\right]$, replacing one of the $\mathrm{L} 1$ molecules, and forming a mixed complex $\left[\mathrm{AscL}_{2} \mathrm{Fe}^{3+}\right]$ with even lower redox activity than $\left[\mathrm{L1}_{3} \mathrm{Fe}^{3+}\right][149]$.

Despite that L1 has a high antioxidant activity and can be used to treat iron and copper overload diseases, such as thalassemia, various forms of siderosis, Friedeich's ataxia, diabetes, Alzheimer's disease, etc. [143,145,154,156-160], the chelator can also exhibit prooxidant activity under certain conditions. The mechanism proposed for the pro-oxidant activity of $\mathrm{L} 1$ involves a reaction between the chelator and the $\mathrm{Fe}^{2+}$ ion present mainly in iron-sulfur clusters [81]. In this context the complexed iron ion transfers its electron to the chelator, which in turn transfers an electron to oxygen with the formation of $\mathrm{O}_{2}{ }^{\bullet-}$ and starts a cascade of redox reactions oxidizing various biomolecules, including aconitase-an iron-containing enzyme [161]. A confirmation mechanism of the pro-oxidant activity of L1 has also been suggested in a similar study [162]. It appears that the chelate complexes of L1 with $\mathrm{Fe}^{2+}$ are considered unstable and decompose to form $\mathrm{Fe}^{3+}$, which in turn is chelated by L1, giving inactive redox complexes [163]. It is noteworthy that no oxidation products are observed in this reaction, which means that L1 is not consumed [163]. The pro-oxidant activity of L1 within the mitochondria and its effect on mitochondrial metabolism has been proposed as the mechanism against cancer cells and an additional pathway promoting L1 for the treatment of cancer [160-162].

Despite the effectiveness of L1, and the preparation/screening of about 100 other KHP, work is in progress to synthesize more new chelators of the KHP group [118,120,122]. In this context and as originally proposed back in 2003, one of the main areas in developing chelating drugs is that of the treatment of neurodegenerative diseases such as Alzheimer's disease, Parkinson's disease and Friedreich's ataxia [143]. Alzheimer's disease is one of the most common neurodegenerative diseases leading to memory impairment and irreversible dementia. The lack of effective treatment methods and the decrease in human life expectancy make this disease a global public health problem [164]. The pathogenesis of Alzheimer's disease is not fully understood, but there are several factors that play an important role in the pathophysiology of this disease, including the presence of extracellular deposits of amyloid plaques $(\mathrm{A} \beta)$, the accumulation of transition metal ions such as $\mathrm{Fe}^{3+}$ and $\mathrm{Cu}^{2+}$ and the oxidative stress caused by them, with uncontrolled generation of ROS and the dysfunction of several important neurotransmitters, in particular acetylcholine (ACh) depletion $[165,166]$. Thus, there are many targets and approaches for the development of new drugs for the treatment of Alzheimer's disease.

There are a fairly large number of single-target investigational new drugs (IND), which have been proposed and tested for Alzheimer's disease, but none has been found or shown to combat the causes and symptoms of the disease at the same time. Within this context, INDs are being synthesized that theoretically can act simultaneously on several targets in Alzheimer's disease. Several structures of multifunctional compounds have been synthesized on the basis of L1, which, in addition to chelating and antioxidant activities, are also capable of affecting other targets of Alzheimer's disease, such as inhibition of amyloid plaque deposits (anti-A $\beta$ ), inhibition of $\mathrm{AChE}$ and an increase in key neurotransmitters due to antagonistic activity histamine $\mathrm{H} 3$ receptor, as presented in Table 2: 
Table 2. Chemical structures of alpha-ketohydroxypyridine hybrids as potential multi-target anti Alzheimer disease drugs.

References *

[169,170]

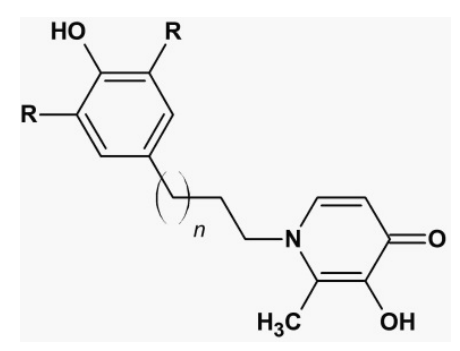

$n=1-3$

$\mathrm{R}=t-\mathrm{Bu}, \mathrm{OCH}_{3}$

AoA

[139]

* Antioxidant activity (AoA), anti-acetylcholinesterase (AChE), anti-amyloid beta aggregation (Abeta) and $\mathrm{H}_{3}$ receptor antagonism $\left(\mathrm{H}_{3} \mathrm{Ra}\right)$.
}

All of the above chelators have antioxidant properties due to the presence of the L1-like 3-hydroxypyrid-one metal binding site in the structure of the molecule [115,142,172,173]. However, the greatest antioxidant activity is observed in the group of bi-tert-butylhydroxytoluene-containing chelators, which are antioxidant scavengers $[115,139]$.

\section{Anthraquinone Chelators}

Anthraquinones, namely quinones of the anthracycline group, are mostly synthetic compounds, some of which belong to quinone-chelators. A feature of some of these compounds is their high antitumor activity. Some quinone-containing drugs/anthracycline antibiotics including doxorubicin (Dox), daunomycin and emodin (Figure 5) have become integral components of therapy regimens for various types of tumors, such as leukemia, lymphoma and breast cancer. The main cytotoxic effect of anthraquinones is to disrupt DNA synthesis, including inhibition of topoisomerase II. In addition, anthraquinones undergo cyclic reduction/oxidation reactions, accompanied by the release of ROS in biological 
electron transfer systems. However, the action of free radicals is also considered responsible for the cardiotoxic effect inherent in this class of compounds [135].<smiles>COc1cccc2c1C(=O)c1c(O)c3c(c(O)c1C2=O)C[C@@](O)(C(=O)CO)C[C@@H]3O[C@H]1C[C@H](N)[C@@H](O)[C@H](C)O1</smiles>

Doxorubicin<smiles>COc1cccc2c1C(=O)c1c(O)c3c(c(O)c1C2=O)C[C@@](O)(C(C)=O)C[C@@H]3O[C@H]1C[C@H](N)[C@@H](O)[C@H](C)O1</smiles>

Daunomycin<smiles>Cc1cc(O)c2c(c1)C(=O)c1cc(O)cc(O)c1C2=O</smiles>

Emodin

Figure 5. Chemical structures of the quinone-chelators doxorubicin (adriamicin, Dox), daunomycin (daunorubicin) and emodin.The metal binding sites of anthraquinones involves an oxygen molecule $(=\mathrm{O})$ of one of the rings and an hydroxyl $(-\mathrm{OH})$ group from an adjacent ring.

There are various reports on the role of chelation by quinones and other chelating agents in the generation of free radicals and in particular the generation of hydroxyl radicals, as well as their effect on lipid peroxidation [174-179]. Some of these data, which are mostly obtained from in vitro studies, describe the mechanisms of the effect of chelators in model reactions in solutions, including the effect of chelation on lipid peroxidation in liposomes and micelles $[176,177,179]$. While a significant part of the work in this area is devoted to the inhibition of lipid oxidation using various chelators [175-177], the major feature of quinone chelators is the enhancement of the generation of free radicals in reactions with metal ions $[178,180]$.

Quinone chelators in the absence of metal ions are themselves capable of generating free radicals and affecting the rate of lipid oxidation $[176,181]$. Although the main mentioned mechanism and mode of action in anticancer therapy related to quinone chelators is DNA binding, the possibility of the existence of additional factors associated with the effect of quinone chelators on the oxidation of unsaturated lipids on the cell membrane has also been suggested [179].

Redox reactions with the participation of anthracycline quinone chelators are usually initiated by the reduction of a quinone molecule with the formation of a semiquinone radical. In this context, the cytochrome P450 enzyme system and the mitochondrial electron transfer chain are among the main sources for the one-electron reduction of quinone. The resulting semiquinone radical can then donate one electron to molecular oxygen, reducing it to the superoxide anion radical, and the semiquinone radical is oxidized back to the original quinone molecule. Thus, this process forms a redox cycle leading to the formation 
of superoxide anion radical and secondary reactive oxygen species (hydrogen peroxide, hydroxyl radical and peroxynitrite) [182].

Superoxide radical and hydrogen peroxide can generate highly reactive hydroxyl radicals in the Fenton reaction, which is catalyzed by transition metal ions [135]. Due to the large number of mitochondria in the myocardium, this mechanism is considered as the main cause of cardiotoxicity of anthracycline antibiotics. In particular, it was also found that there was an increase in the level of ROS after treatment with Dox both on cell lines and in animals. Biomarkers of oxidative stress are also elevated in human cancer patients treated by Dox. The most widely known mechanism of this observation is the ability of Dox to participate in redox reactions with the formation of ROS [137]. Some studies associate the cardiotoxicity of anthracyclines, and in particular Dox and daunomycin, with the ability to initiate the release of iron from the iron-storage protein ferritin [183]. It was argued that, in the presence of NADPH-cytochrome P-450 reductase, these drugs undergo a redox cycle with the formation of superoxide, which provides a slow release of iron from ferritin. In this case, the rapid release of iron from the ferritin is observed under anaerobic conditions, when there is no reaction of the semiquinone radical with oxygen. It was concluded that the semiquinone radicals of Dox and daunomycin are capable of directly releasing redox active iron that was previously deposited in ferritin [183].

However, there are studies indicating a different role for anthracyclines in iron metabolism. In particular, it was shown that Dox inhibits the release of iron from ferritin, which leads to accumulation and deposition of iron ions in this protein [183]. The authors attributed the difference of these conclusions from the results obtained on intact cell systems, while the work was carried out with the isolated protein ferritin [183]. It was suggested that the structure and functions of isolated protein may be different to the cellular protein in the cellular environment [184].

Another possible mechanism of anthracyclines cardiotoxicity is associated with their role in lipid peroxidation reactions. In particular, in vivo studies have shown that the yield of malondialdehyde, one of the markers of lipid peroxidation, in the cardiac tissues of experimental animals increases significantly in the presence of Dox [185]. It has also been shown that this quinone induces the formation of conjugated dienes as a result of lipid peroxidation in cardiomyocyte cells in vitro, which is accompanied by subsequent disruption of membrane integrity [186]. It appears that the release of iron from ferritin can lead to an increase in the fraction of free intracellular $\mathrm{Fe}^{2+}$, the subsequent formation of hydroxyl radicals, which can then initiate lipid peroxidation [183].

Quinones of the anthracycline group are widely used in medicine not only as highly effective cytotoxic agents in tumor chemotherapy, but also in photodynamic therapy. This approach makes it possible to locally activate the anticancer agent, increasing the specificity of the drug, and, thus, reducing the overall toxic side effects. Photodynamic therapy is a form of cancer treatment that is highly selective for tumor cells. The essence of this therapy is the formation of singlet oxygen and free radicals in the reaction of a photosensitizer with light of a suitable wavelength $[187,188]$. Singlet oxygen is a highly reactive molecule that oxidizes carbon-carbon bonds and can damage various components of the target cell (lipids, proteins, nucleic acids), which directly leads to the death of the tumor cell [188]. Photodynamic therapy of skin diseases is especially relevant due to the accessibility of tumor-affected areas to light [189]. However, it can also be used to treat other types of tumors by bringing thin light guides to the affected tissues [190]. Therefore, the search of effective agents is also quite relevant for photodynamic therapy.

Transition metal complexes that absorb light in the range suitable for photodynamic therapy $(500-800 \mathrm{~nm})$ have also been studied and shown to exhibit high cytotoxic activity against tumor cells of various histological origin [178,191-193]. Similarly, complexes of anthraquinones with transition metal ions demonstrated higher cytotoxicity under the influence of light (IC50 2-11 $\mu \mathrm{M}$ ) in comparison to only anthraquinones, and also low cytotoxicity under dark conditions (IC50 > 50 $\mu \mathrm{M}$ ) [193]. The enhancement of photo-cytotoxicity in the chelate complex with a copper ion appears from quantum-chemical calculations 
to occur due to the formation of a low-lying long-lived triplet state, which enhances the quinone's ability to generate singlet oxygen by the energy transfer mechanism [193].

One of the first features of quinone chelate complexes is the appearance of a new light absorption band in the visible region (500-800 nm), which is more suitable for photodynamic therapy due to deeper penetration into living tissues [194]. In comparison, the light absorption region of the starting quinones lies in the UV range of 300-500 $\mathrm{nm}[195,196]$.

Another feature of photoinduced processes involving chelate complexes of quinones is an increase in the yield of semiquinone radicals and ROS [178,180]. An increase in the yield of hydroxyl radicals in the presence of iron and zinc ions has been shown using EPR with spin traps in the presence of the quinone-chelators 2-phenyl-4-(butylamino)naphtho [2,3-h] quinoline-7,12-dione (Q1) and doxorubicin (Figures 5 and 6) [178].

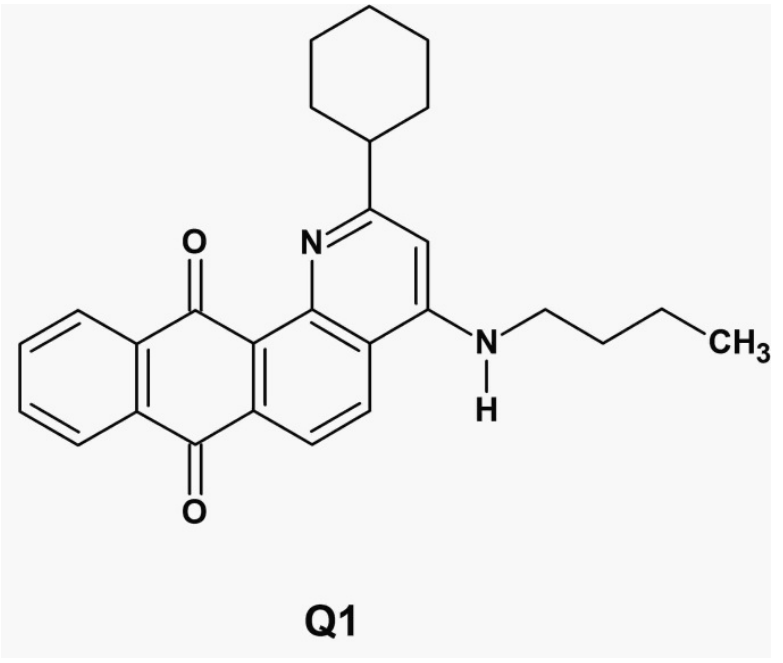

Figure 6. Chemical structure of the athraquinone-chelator 2-phenyl-4-(butylamino)naphtho[2,3-h] quinoline-7,12-dione (Q1).

The formation of a semiquinone radical $\left(\mathrm{Q}^{-\bullet}\right)$ is a prerequisite for the formation of ROS upon reduction of quinones in the dark and upon excitation with visible light as shown in Equations (3), (12)-(16) [180]. The most likely biological electron donors for quinone molecules are glutathione (GSH) and the coenzyme NADH, which are present in cells at high concentrations $[180,197,198]$.

$$
\begin{gathered}
\mathrm{Q}+\mathrm{e} \rightarrow \dot{\mathrm{Q}}^{-} \\
\dot{\mathrm{Q}}^{-}+\mathrm{O}_{2} \leftrightarrow \mathrm{Q}+\dot{\mathrm{O}}_{2}^{-} \\
\dot{\mathrm{O}}_{2}^{-}+\dot{\mathrm{O}}_{2}^{-} \stackrel{2}{\rightarrow} \mathrm{H}_{2} \mathrm{O}_{2}+\mathrm{O}_{2} \\
\dot{\mathrm{O}}_{2}^{-}+\mathrm{H}_{2} \mathrm{O}_{2} \rightarrow \mathrm{O}_{2}+\mathrm{HO}^{-}+\mathrm{HO} \\
\dot{\mathrm{Q}}^{-}+\mathrm{Fe}^{3+} \rightarrow \mathrm{Q}+\mathrm{Fe}^{2+}
\end{gathered}
$$

In addition, ascorbic acid can also react with anthraquinones and their chelate complexes with $\mathrm{Fe}^{2+}$ ions as an electron donor as shown in Equations (17) and $(18)[97,199]$.

$$
\begin{aligned}
& \mathrm{Q}+\mathrm{AscH}^{-}\left(\text {or } \mathrm{AscH}_{2}\right) \rightarrow \dot{\mathrm{QH}}+\dot{\mathrm{Asc}}^{-}\left(\text {or } \mathrm{AscH}^{-}\right) \\
& \mathrm{QFe}^{2+}+\mathrm{AscH}^{-}\left(\text {or } \mathrm{AscH}_{2}\right) \rightarrow \mathrm{Fe}^{2+} \dot{\mathrm{Q}}^{-}+\mathrm{H}^{+}+\mathrm{Asc}^{-} \text {(or } \mathrm{AscH}^{-} \text {) }
\end{aligned}
$$

Thus, ascorbic acid generates an additional channel for the reaction leading to ROS formation in the presence of anthraquinones $[97,98,199]$. This suggests the possible use of a 
combination of anticancer therapy with the participation of anthraquinones and ascorbic acid $[97,98,200,201]$.

An increase of the yield of semiquinone radicals, as well as the NADH radical cation, was demonstrated in a model photoreaction in solution by the EPR and CIDNP methods in the presence of metal ions [178,180].

The principal property of the proposed mechanism in the reaction Equations (3), (12)-(16) is redox cycling (as a result of cyclic reduction of quinone), followed by the next oxidation of semiquinone with molecular oxygen. The Fenton reaction with the generation of a hydroxyl radical can take place not only in the presence of iron ions Equations (3), (12)-(16), but also in the presence of copper ions [88]. Due to their high reactivity and short lifetime, hydroxyl radicals must be formed in the vicinity of potential targets, thus causing local damage. The cyclic nature of the process should permit the inactivation of multiple copies of the target, thus allowing the use of low doses of reagent, with a concomitant reduction in toxic side effects. It should be noted that the detected increase in the yield of semiquinone radicals and ROS in the presence of metal ions was observed only for quinones-chelators but was absent for quinones that do not contain chelating groups [178,180].

An additional factor of the influence on the efficiency of electron transfer processes with the participation of quinones-chelators is the differential effect of metal ions such as $\mathrm{Zn}^{2+}, \mathrm{Ca}^{2+}, \mathrm{Cu}^{2+}$ and $\mathrm{Fe}^{3+}$ on the reduction potentials of quinones, for example Q1 and 1-amino-4-hydroxy-9,10-anthraquinone $[178,198]$. The increase of the electrode potential of quinone Q1 was about $0.5 \mathrm{~V}$ for the $\mathrm{Zn}^{2+}, \mathrm{Ca}^{2+}$, and $\mathrm{Fe}^{3+}$ complexes. Since non-transition metal ions do not participate in the generation of ROS by the Fenton reaction, it can be assumed that the increase of the quinone reduction potential effects the increase of the yield of semiquinone radicals in the presence of zinc ions as recorded by the EPR method [178] (see Scheme 1). A significant effect of complexation with the $\mathrm{Cu}^{2+}$ ion on the electrochemical behavior of 1-amino-4-hydroxy-9,10-anthraquinone, and in particular the stabilization of semiquinone, as a result of the redistribution of the electron density under the influence of the positive charge of the metal ion has also been noted [198]. It was suggested that this effect could reduce the ability of the semiquinone in complex with the copper ion to interact with molecular oxygen. Thus, in the case of the copper complex, there is a general decrease in the formation of $\mathrm{O}_{2}{ }^{\bullet-}$ compared to free 1-amino-4-hydroxy-9,10-anthraquinone. It can be suggested from this study that the copper chelate complex will be less cardiotoxic than the parent quinone and can be considered for possible use in the treatment of cancer.

The effect of enhancing the activity of Dox in the presence of metal ions $(\mathrm{Mg}, \mathrm{Mn}, \mathrm{Co}$, $\mathrm{Ni}, \mathrm{Fe}, \mathrm{Cu}, \mathrm{Zn}$ ) was also studied in vitro [195]. It was shown that Dox forms complexes with quinone-metal stoichiometry of 2:1 with bivalent metals, and 3:1 with $\mathrm{Fe}^{3+}$. A high antitumor activity of chelate complexes has been shown in the MCF-7 breast cancer cell model. Overall, it was concluded that selective quinone-metal complexes can be considered as new potential anticancer agents with higher efficiency than free quinones. However, further toxicological studies are needed, including studies of the molecular mechanisms of action of such complexes and possible changes in the signaling pathways of oxidative stress under the influence of the test compound.

\section{Thiosemicarbazone Chelators}

Thiosemicarbazones is another class of redox-active chelators which are of a great interest for scientists from various fields of science. In the PubMed database, a sharp surge in the number of publications devoted to these compounds is observed since the mid-2000s. The high interest stems from the wide range of their chemical and biological activity including their antimicrobial, antiviral and antitumor effects [202-205]. Some of the TSCs, such as triapine, have reached the stage of clinical trials in different categories of cancer patients, with encouraging anticancer effects [28,206-210] (Figure 7). The anticancer activity of TSCs was initially associated with the ability to inhibit ribonucleotide reductase [28,206-211]. Ribonucleotide reductase is an iron containing enzyme that converts all four ribonucleotides into their deoxyribonucleotide analogs, which plays an important role in DNA synthesis. 
Iron is of great importance for the catalytic activity of ribonucleotide reductase and stabilizes the tyrosyl radical located in one of the enzyme subunits. This makes iron a possible target for chemotherapy drugs [212].<smiles>CN(C)C(=S)NN=C(c1ccccn1)c1ccccn1</smiles>

Dp44mT<smiles></smiles>

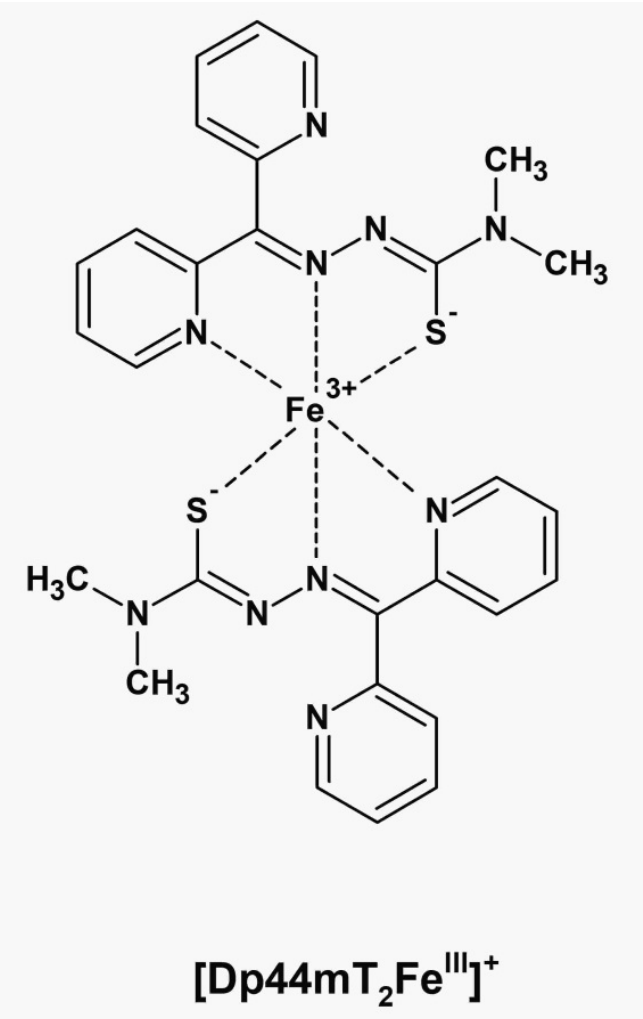

\section{Triapine}

Figure 7. Chemical structures of 3-aminopyridine-2-carboxaldehyde thiosemicarbazone (triapine), di-2-pyridylketone-4,4,-dimethyl-3-thiosemicarbazone (Dp44mT) and its chelate complex with iron ion.

The ability of TSC s to chelate metal ions is currently recognized as one of the main factors in their antiproliferative action at least by some investigators [213]. The redox activity of the complexes of TSCs with iron is of decisive importance in their anticancer activity, which is related to oxidative damage and inhibition of ribonucleotide reductase. Furthermore, the chelation of transition metals and in particular intracellular iron, can lead to inhibition of several other iron-containing proteins including ribonucleotide reductase [214]. Overall it appears that tumor cells have a higher level of ribonucleotide reductase than normal cells, and therefore are more sensitive to iron chelation [215]. In vivo studies and clinical trials have suggested that some TSCs can be developed and used as chemotherapeutic agents [28,206-210,215,216].

Recent studies have indicated a major role of redox activity and oxidative stress increase in the anticancer activity of TSCs [217]. A distinctive feature of the complexes of TSCs with iron is a rather high formal electrode potential of the $\mathrm{Fe}^{3+/} \mathrm{Fe}^{2+}$ pair, from +100 to $+250 \mathrm{mV}[213,217,218]$. This leads to a higher stability of complexes with $\mathrm{Fe}^{2+}$ compared to complexes with $\mathrm{Fe}^{3+}$ [219]. In contrast, chelators used to treat diseases associated with excess iron, such as L1 and deferasirox, have a low redox potential of the $\mathrm{Fe}^{3+/} \mathrm{Fe}^{2+}$ pair, from -400 to $-600 \mathrm{mV}$, which leads to a significantly higher stability of the complexes. with $\mathrm{Fe}^{3+}$ [219].

In general, $\mathrm{Fe}^{2+}$ in a complex with TSCs retains its redox catalytic activity. For example in the case the TSC chelator di-2-pyridylketone-4,4,-dimethyl-3-thiosemicarbazone $(\mathrm{Dp} 44 \mathrm{mT}), \mathrm{Fe}^{2+}$ is converted to $\mathrm{Fe}^{3+}$ in $\mathrm{Dp} 44 \mathrm{mT}$ complexes via the reaction with molecu- 
lar oxygen [220,221]. The proposed mechanism of the reactions proceeding in the buffer solution at $\mathrm{pH} 7.1$ is shown in Equations (19)-(26) [221].

$$
\begin{gathered}
{\left[\mathrm{Fe}^{2+}(\mathrm{TSC})_{2}\right]+\mathrm{H}^{+} \stackrel{\mathrm{K}}{\leftrightarrow}\left[\mathrm{Fe}^{2+}(\mathrm{TSC})_{2} \mathrm{H}\right]^{+}} \\
{\left[\mathrm{Fe}^{2+}(\mathrm{TSC})_{2}\right]+\mathrm{O}_{2} \stackrel{\mathrm{k}_{\text {ox }}}{\rightarrow}\left[\mathrm{Fe}^{2+}(\mathrm{TSC})_{2}\right]^{+}+\dot{\mathrm{O}}_{2}{ }^{-}} \\
{\left[\mathrm{Fe}^{2+}(\mathrm{TSC})_{2} \mathrm{H}\right]^{+}+\mathrm{O}_{2} \stackrel{\mathrm{k}_{\text {ox }}}{\rightarrow}\left[\mathrm{Fe}^{3+}(\mathrm{TSC})_{2}\right]^{+}+\mathrm{HO}_{2}} \\
{\left[\mathrm{Fe}^{2+}\right]+\dot{\mathrm{O}}_{2}{ }^{-}+2 \mathrm{H}^{+} \rightarrow\left[\mathrm{Fe}^{3+}\right]+\mathrm{H}_{2} \mathrm{O}_{2}} \\
{\left[\mathrm{Fe}^{2+}\right]+\mathrm{HO}_{2}+\mathrm{H}^{+} \rightarrow\left[\mathrm{Fe}^{3+}\right]+\mathrm{H}_{2} \mathrm{O}_{2}} \\
{\left[\mathrm{Fe}^{2+}\right]+\mathrm{H}_{2} \mathrm{O}_{2}+\mathrm{H}^{+} \rightarrow\left[\mathrm{Fe}^{3+}\right]+\dot{\mathrm{O}}+\mathrm{H}_{2} \mathrm{O}} \\
2 \dot{\mathrm{O}}_{2}^{-}+2 \mathrm{H}^{+} \rightarrow \mathrm{O}_{2}+\mathrm{H}_{2} \mathrm{O}_{2} \\
2 \mathrm{H}_{2} \mathrm{O}_{2} \rightarrow \mathrm{O}_{2}+2 \mathrm{H}_{2} \mathrm{O}
\end{gathered}
$$

In the above equations, TSC is thiosemicarbazone and square brackets indicate chelate complex with various ligands in solution such as anions or water. Furthermore, since the complex of iron ion with TSCs is redox active, ascorbic acid is able to interact with it Equation (27) with the further formation of ROS Equations (20)-(26):

$$
\left[\mathrm{Fe}^{3+}(\mathrm{TSC})_{2}\right]^{+}+\mathrm{AscH}_{2}\left(\text { or } \mathrm{AscH}^{-}\right) \rightarrow\left[\mathrm{Fe}^{2+}(\mathrm{TSC})_{2}\right]+\mathrm{AscH}\left(\mathrm{Asc}{ }^{-}\right)+\mathrm{H}^{+}
$$

This effect was demonstrated in studies using the EPR method with spin traps [222].

In the case of anthracycline antibiotics, there is an increase in the yield of the hydroxyl radicals in the Fenton reaction in the presence of TSCs, in particular the Dp44mT (Figure 7) [222]. A number of TSCs also demonstrate a significant increase in the yield of ROS in experiments in cell cultures of HCT116 (colon cancer), accompanied by cell death [216].

An important factor affecting the activity of TSCs is their hydrophobicity or lipophilicity. The octanol/water partition coefficient $(\log \mathrm{P})$ can be a measure of this factor. It has been shown that the most hydrophobic TSCs $(\log \mathrm{P}>2)$ and the most hydrophilic $(\log \mathrm{P}<1.5)$ demonstrate a worse antiproliferative effect than TSCs with $\log P 1.5-2.0[213,217]$. The probable reason is that the most hydrophilic compounds are difficult to pass through the cell membrane, while highly hydrophobic molecules will accumulate in the membranes due to their high affinity for the lipid environment.

Complexes of TSCs with copper and zinc also have an antiproliferative effect. Thus, the complexes of Dp44mT and di-2-pyridylketone-4-cyclohexyl-4-methyl-3-thiosemicarbazone $(\mathrm{DpC})$ with zinc were found to exhibit higher cytotoxicity than free ligands (Figure 8) [223]. Microscopy with fluorescent labels showed that TSCs penetrate into lysosomes with the formation of copper chelate complexes, promoting the formation of ROS, membrane oxidation and cell death. It has been proposed that this mechanism of action is also related to the anticancer activity of TSCs [223,224]. 
<smiles>CN(C(=S)NN=C(c1ccccn1)c1ccccn1)C1CCCCC1</smiles>

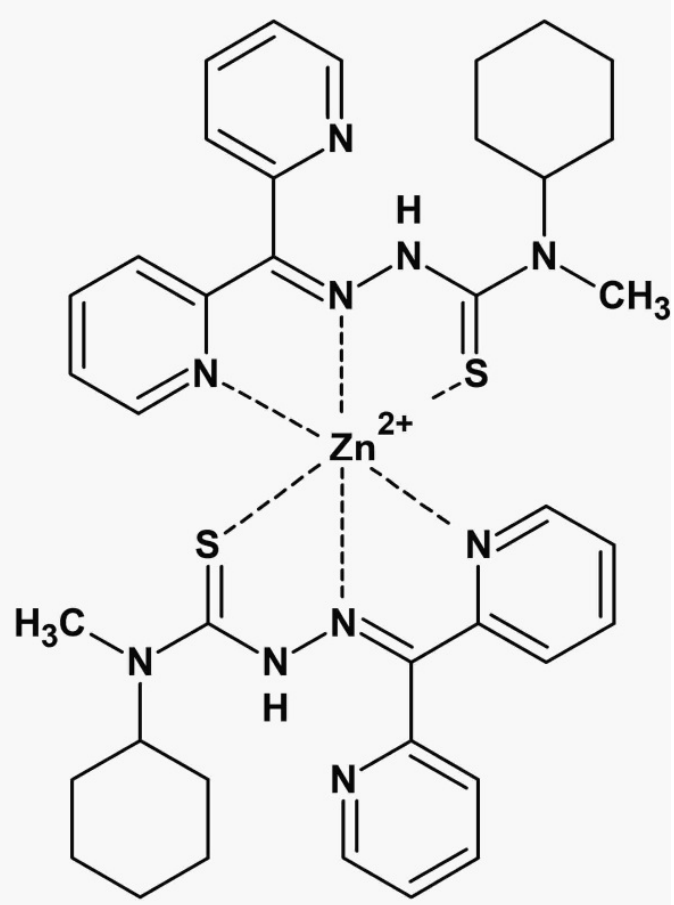

Figure 8. Chemical structures of di-2-pyridylketone-4-cyclohexyl-4-methyl-3-thiosemicarbazone $(\mathrm{DpC})$ and its chelate complex with zinc ion.

However, this mechanism, which includes lipid peroxidation in membranes, is not characteristic of all compounds of this class. Thus, studies have shown that the complexes of 2((E)-3-(4-chlorophenyl)-1-phenylallylidene)- $N$-phenyl-hydrazinecarbothioamide (HL1) and 2-((E)-3-(4-cyanophenyl)-1-phenylallylidene)- $N$-phenyl-hydrazinecarbothioamide (HL4) (Figure 9) with copper have an antiproliferative effect in experiments on S. cerevisiae cells [225]. However, difference in the mechanism of action has been proposed where, in the case of HL4, the effects are on proliferation by preventing the formation of viable daughter cells, whereas, in the case of HL1, the effects are related to the induction of lipid peroxidation in the plasma membrane [225].<smiles>[R]c1ccc(/C=C/C(=N/NC(=S)Nc2ccccc2)c2ccccc2)cc1</smiles>

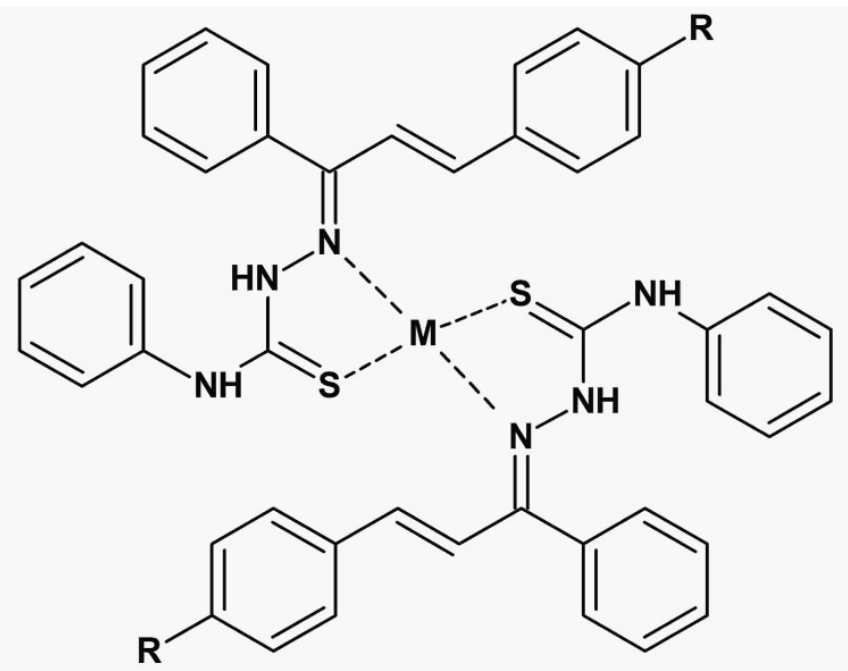

Figure 9. Chemical structures of 2-((E)-3-(4-chlorophenyl)-1-phenylallylidene)-N-phenylhydrazinecarbothioamide (HL1, R = Cl) and 2-((E)-3-(4-cyanophenyl)-1-phenylallylidene)- $N-$ phenyl-hydrazinecarbothioamide ( $\mathrm{HL} 4, \mathrm{R}=\mathrm{CN})$ and their complexes with metal ions $(\mathrm{M})$. 
It has also been shown that complex formation with copper leads to an increase in the selectivity of the TSCs against melanoma cells. For example, complexes of triapine with copper exhibit greater cytotoxicity in relation to tumor cells and less in relation to normal cells than the free ligand [226-231]. Copper accumulates in tumor cells due to the selective permeability of cancer cell membranes. In general it was found that many complexes of TSCs with copper are active against malignant tumors both in in vitro and in vivo tests $[97,226-230]$.

\section{Conclusions}

The redox properties of chelating drugs and their metal complexes, which are used to treat various diseases, are one of the central factors in their therapeutic activity and a major aspect of their toxicity. In the case of oxidative stress caused by the catalytic activity of iron and copper, some chelators are used to inhibit the redox activity of these metal ions. Conversely, in some forms of cancer treatment, metal complexes are required, which have redox activity and can enhance the redox properties of bounded metal ions. The spectrum of chelator mechanisms that affect the redox activity of complexed metals is quite diverse and includes the ability of the chelator to participate in redox reactions, a change in the electrode potential of the metal in the complex and the creation/preservation of the coordination center for metal binding in the complex. In this review, the diversity of molecular properties and redox mechanistic insights of chelating drugs and chelator metal complexes with a wide range of potential therapeutic uses has been shown with emphasis three major prototype groups, namely the alpha-ketohydroxypyridines, anthraquinones, and thiosemicarbazones. Different therapeutic possibilities can be envisaged in this series of chelators including the possibility of modifying the basic chemical structure and adding functional groups, which can potentially lead to multi-target therapy of various pathologies, for example, in Alzheimer's disease. In addition, the physicochemical and chelating properties of ascorbic acid are described, as well as the possibility of its use together with other chelating drugs or agents in combination therapies for the treatment of various pathologies. It should be noted that despite the progress and development in this area, the physicochemical, biological and toxicological properties of new chelators have not yet been fully investigated; additional in vitro, in vivo, and clinical studies are needed for the development of related therapeutics in cancer, neurodegenerative and other diseases.

Author Contributions: Conceptualization, V.A.T., N.E.P. and G.J.K.; validation, N.E.P., O.Y.S. and G.J.K.; writing-original draft preparation, V.A.T., O.Y.S., N.E.P. and G.J.K.; writing-review and editing, V.A.T., N.E.P., O.Y.S., V.D. and G.J.K.; visualization, V.A.T. and O.Y.S.; supervision, V.A.T., N.E.P. and G.J.K.; project administration, V.A.T. and G.J.K.; funding acquisition, O.Y.S. and G.J.K. All authors have read and agreed to the published version of the manuscript.

Funding: This research was supported by grant from the Russian Science Foundation (No. 2173-10037) and by internal funds of the Postgraduate Research Institute of Science, Technology, Environment and Medicine of Cyprus.

Institutional Review Board Statement: Not applicable.

Informed Consent Statement: Not applicable.

Data Availability Statement: Data is contained within the article.

Conflicts of Interest: The authors declare no conflict of interest. 
Abbreviations

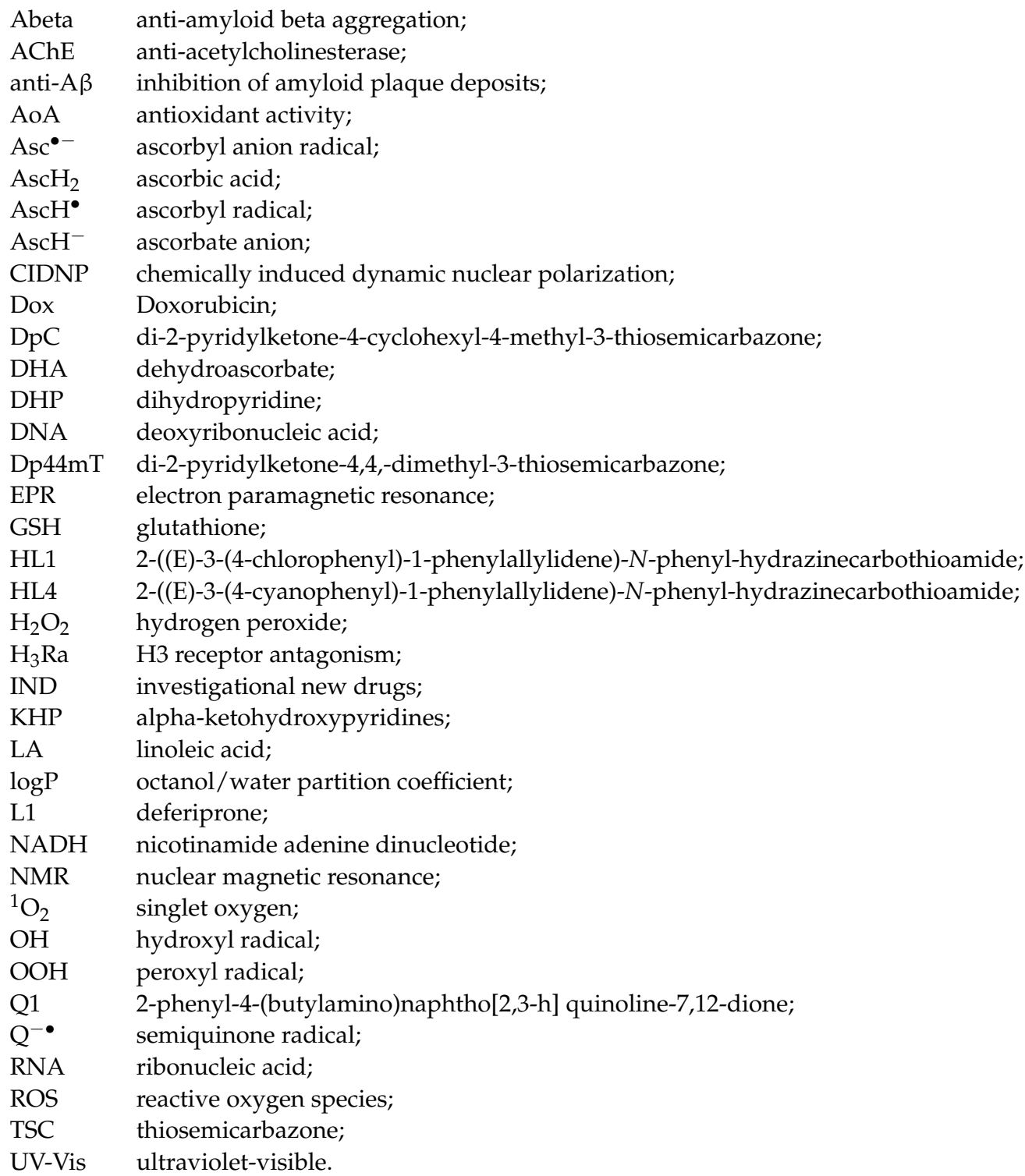

\section{References}

1. Halliwell, B.; Gutteridge, J.M.C. Editorial: Free Radicals and Antioxidant Protection: Mechanisms and Significance in Toxicology and Disease. Hum. Exp. Toxicol. 1988, 7, 7-13. [CrossRef] [PubMed]

2. Denisov, E.T.; Afanas'ev, I.B. Oxidation and Antioxidants in Organic Chemistry and Biology; Taylor \& Francis: Abingdon, UK, 2005; ISBN 9780824753566.

3. Kontoghiorghes, G.J. Iron Chelation in Biochemistry and Medicine. In Free radicals, Oxidant Stress and Drug Action; Rice-Evans, C., Ed.; Rechelieu Press: London, UK, 1987; pp. 277-303.

4. Halliwell, B.; Gutteridge, J.M.; Cross, C.E. Free Radicals, Antioxidants, and Human Disease: Where Are We Now? J. Lab. Clin. Med. 1992, 119, 598-620. [PubMed]

5. Ďuračková, Z. Some Current Insights into Oxidative Stress. Physiol. Res. 2010, 59, 459-469. [CrossRef] [PubMed]

6. Stangherlin, A.; Reddy, A.B. Regulation of Circadian Clocks by Redox Homeostasis. J. Biol. Chem. 2013, 288, $26505-26511$. [CrossRef] [PubMed]

7. Santucci, R.; Sinibaldi, F.; Cozza, P.; Polticelli, F.; Fiorucci, L. Cytochrome c: An Extreme Multifunctional Protein with a Key Role in Cell Fate. Int. J. Biol. Macromol. 2019, 136, 1237-1246. [CrossRef]

8. Ramzan, R.; Vogt, S.; Kadenbach, B. Stress-Mediated Generation of Deleterious ROS in Healthy Individuals—Role of Cytochrome c Oxidase. J. Mol. Med. 2020, 98, 651-657. [CrossRef]

9. Cabon, L.; Martinez-Torres, A.C.; Susin, S.A. Programmed Cell Death Comes in Many Flavors. Med. Sci. 2013, 29, 1117-1124. [CrossRef] 
10. Speer, R.E.; Karuppagounder, S.S.; Basso, M.; Sleiman, S.F.; Kumar, A.; Brand, D.; Smirnova, N.; Gazaryan, I.; Khim, S.J.; Ratan, R.R. Hypoxia-Inducible Factor Prolyl Hydroxylases as Targets for Neuroprotection by "Antioxidant" Metal Chelators: From Ferroptosis to Stroke. Free Radic. Biol. Med. 2013, 62, 26-36. [CrossRef]

11. Feng, H.; Stockwell, B.R. Unsolved Mysteries: How Does Lipid Peroxidation Cause Ferroptosis? PLoS Biol. 2018, 16, e2006203. [CrossRef]

12. Shah, R.; Shchepinov, M.S.; Pratt, D.A. Resolving the Role of Lipoxygenases in the Initiation and Execution of Ferroptosis. ACS Cent. Sci. 2018, 4, 387-396. [CrossRef]

13. Hao, S.; Liang, B.; Huang, Q.; Dong, S.; Wu, Z.; He, W.; Shi, M. Metabolic Networks in Ferroptosis. Oncol. Lett. 2018, $15,5405-5411$. [CrossRef] [PubMed]

14. Tang, D.; Chen, X.; Kang, R.; Kroemer, G. Ferroptosis: Molecular Mechanisms and Health Implications. Cell Res. 2021, 31, 107-125. [CrossRef]

15. Yan, N.; Zhang, J.J. Iron Metabolism, Ferroptosis, and the Links with Alzheimer's Disease. Front. Neurosci. 2020, 13, 1443. [CrossRef] [PubMed]

16. Martinet, W.; Coornaert, I.; Puylaert, P.; De Meyer, G.R.Y. Macrophage Death as a Pharmacological Target in Atherosclerosis. Front. Pharmacol. 2019, 10, 306. [CrossRef]

17. Ravingerová, T.; Kindernay, L.; Barteková, M.; Ferko, M.; Adameová, A.; Zohdi, V.; Bernátová, I.; Ferenczyová, K.; Lazou, A. The Molecular Mechanisms of Iron Metabolism and Its Role in Cardiac Dysfunction and Cardioprotection. Int. J. Mol. Sci. 2020, 21, 7889. [CrossRef] [PubMed]

18. Apel, K.; Hirt, H. Reactive Oxygen Species: Metabolism, Oxidative Stress, and Signal Transduction. Annu. Rev. Plant Biol. 2004, 55, 373-399. [CrossRef] [PubMed]

19. Mittler, R. Oxidative Stress, Antioxidants and Stress Tolerance. Trends Plant Sci. 2002, 7, 405-410. [CrossRef]

20. Valko, M.; Leibfritz, D.; Moncol, J.; Cronin, M.T.D.; Mazur, M.; Telser, J. Free Radicals and Antioxidants in Normal Physiological Functions and Human Disease. Int. J. Biochem. Cell Biol. 2007, 39, 44-84. [CrossRef] [PubMed]

21. Kontoghiorghes, G.J. Regulatory Molecules and Chelators Used for the Control of Essential and Toxic Metals in Health and Disease: From Molecular Interactions to Clinical Effects and Applications. Curr. Med. Chem. 2005, 12, 2661-2662. [CrossRef]

22. Kontoghiorghes, G.J.; Aldouri, M.A.; Hoffbrand, A.V.; Barr, J.; Wonke, B.; Kourouclaris, T.; Sheppard, L. Effective Chelation of Iron in $\beta$ Thalassaemia with the Oral Chelator 1,2-Dimethyl-3-Hydroxypyrid-4-One. Br. Med. J. 1987, 295, 1509-1512. [CrossRef]

23. Kolnagou, A.; Kleanthous, M.; Kontoghiorghes, G.J. Reduction of Body Iron Stores to Normal Range Levels in Thalassaemia by Using a Deferiprone/Deferoxamine Combination and Their Maintenance Thereafter by Deferiprone Monotherapy. Eur. J. Haematol. 2010, 85, 430-438. [CrossRef] [PubMed]

24. Baldari, S.; Di Rocco, G.; Toietta, G. Current Biomedical Use of Copper Chelation Therapy. Int. J. Mol. Sci. 2020, $21,1069$. [CrossRef] [PubMed]

25. Kontoghiorghes, G.J.; Piga, A.; Hoffbrand, A.V. Cytotoxic Effects of the Lipophilic Iron Chelator Omadine. FEBS Lett. 1986, 204, 208-212. [CrossRef]

26. Kontoghiorghes, G.J.; Piga, A.; Hoffbrand, A.V. Cytotoxic and DNA-inhibitory Effects of Iron Chelators on Human Leukaemic Cell Lines. Hematol. Oncol. 1986, 4, 195-204. [CrossRef] [PubMed]

27. Ganeshaguru, K.; Lally, J.M.; Piga, A.; Hoffbrand, A.V.; Kontoghiorghes, G.J. Cytotoxic Mechanisms of Iron Chelators. Drugs Today 1992, 28, 29-34.

28. Nutting, C.M.; Van Herpen, C.M.L.; Miah, A.B.; Bhide, S.A.; Machiels, J.P.; Buter, J.; Kelly, C.; De Raucourt, D.; Harrington, K.J. Phase II Study of 3-AP Triapine in Patients with Recurrent or Metastatic Head and Neck Squamous Cell Carcinoma. Ann. Oncol. Off. J. Eur. Soc. Med. Oncol. 2009, 20, 1275-1279. [CrossRef]

29. Wagner, R.R. Chemical and Biologic Approaches to the Therapy of Viral Diseases. Am. Rev. Respir. Dis. 1963, 88, 404-419. [CrossRef]

30. Bove, F.; Fasano, A. Iron Chelation Therapy to Prevent the Manifestations of Aceruloplasminemia. Neurology 2015, 85, 1085-1086. [CrossRef]

31. Romanova, A.S. Natural Anthraquinones. Farmatsiia 1968, 17, 71-76.

32. Steere, A.N.; Byrne, S.L.; Chasteen, N.D.; Mason, A.B. Kinetics of Iron Release from Transferrin Bound to the Transferrin Receptor at Endosomal PH. Biochim. Biophys. Acta-Gen. Subj. 2012, 1820, 326-333. [CrossRef]

33. Pantopoulos, K.; Porwal, S.K.; Tartakoff, A.; Devireddy, L. Mechanisms of Mammalian Iron Homeostasis. Biochemistry 2012, 51, 5705-5724. [CrossRef] [PubMed]

34. Gozzelino, R.; Arosio, P. Iron Homeostasis in Health and Disease. Int. J. Mol. Sci. 2016, 17, 130. [CrossRef] [PubMed]

35. Anderson, G.J.; Frazer, D.M. Current Understanding of Iron Homeostasis. Am. J. Clin. Nutr. 2017, 106 (Suppl.6), 1559S-1566S. [CrossRef] [PubMed]

36. DeLoughery, T.G. Iron Deficiency Anemia. Med. Clin. N. Am. 2017, 101, 319-332. [CrossRef] [PubMed]

37. Weatherall, D.J.; Clegg, J.B. Inherited Haemoglobin Disorders: An Increasing Global Health Problem. Bull. World Health Organ. 2001, 79, 704-712. [CrossRef]

38. Kontoghiorghes, G.J. How to Manage Iron Toxicity in Post-Allogeneic Hematopoietic Stem Cell Transplantation? Expert Rev. Hematol. 2020, 13, 299-302. [CrossRef]

39. Rees, D.C.; Williams, T.N.; Gladwin, M.T. Sickle-Cell Disease. Lancet 2010, 376, 2018-2031. [CrossRef] 
40. Fitzsimons, E.J.; Cullis, J.O.; Thomas, D.W.; Tsochatzis, E.; Griffiths, W.J.H. Diagnosis and Therapy of Genetic Haemochromatosis (Review and 2017 Update). Br. J. Haematol. 2018, 181, 293-303. [CrossRef]

41. Milman, N.T.; Schioedt, F.V.; Junker, A.E.; Magnussen, K. Diagnosis and Treatment of Genetic HFE-Hemochromatosis: The Danish Aspect. Gastroenterol. Res. 2019, 12, 221-232. [CrossRef]

42. Holm, R.H.; Kennepohl, P.; Solomon, E.I. Structural and Functional Aspects of Metal Sites in Biology. Chem. Rev. 1996, 2123, 2239-2314. [CrossRef]

43. Erdman, J.W.; MacDonald, I.; Zeisel, S.H.; International Life Sciences Institute. Present Knowledge in Nutrition; International Life Sciences Institute: Washington, DC, USA; John Wiley and Sons Inc.: Hoboken, NJ, USA, $2012 ;$ ISBN 9780470959176.

44. Prohaska, J.R. Impact of Copper Limitation on Expression and Function of Multicopper Oxidases (Ferroxidases). Adv. Nutr. Int. Rev. J. 2011, 2, 89-95. [CrossRef]

45. Vashchenko, G.; MacGillivray, R. Multi-Copper Oxidases and Human Iron Metabolism. Nutrients 2013, 5, 2289-2313. [CrossRef]

46. Best, K.; McCoy, K.; Gemma, S.; DiSilvestro, R.A. Copper Enzyme Activities in Cystic Fibrosis before and after Copper Supplementation plus or Minus Zinc. Metabolism 2004, 53, 37-41. [CrossRef] [PubMed]

47. Jones, A.A.; DiSilvestro, R.A.; Coleman, M.; Wagner, T.L. Copper Supplementation of Adult Men: Effects on Blood Copper Enzyme Activities and Indicators of Cardiovascular Disease Risk. Metabolism 1997, 46, 1380-1383. [CrossRef]

48. Daniel, K.G.; Harbach, R.H.; Guida, W.C.; Dou, Q.P. Copper Storage Diseases: Menkes, Wilsons, and Cancer. Front. Biosci. 2004, 9, 2652-2662. [CrossRef]

49. Afanas'ev, I.B. Superoxide and Nitric Oxide in Pathological Conditions Associated with Iron Overload. The Effects of Antioxidants and Chelators. Curr. Med. Chem. 2005, 12, 2731-2739. [CrossRef] [PubMed]

50. Traber, M.G.; Stevens, J.F. Vitamins C and E: Beneficial Effects from a Mechanistic Perspective. Free Radic. Biol. Med. 2011, 51, 1000-1013. [CrossRef] [PubMed]

51. Turan, B. Role of Antioxidants in Redox Regulation of Diabetic Cardiovascular Complications. Curr. Pharm. Biotechnol. 2010, 11, 819-836. [CrossRef]

52. Ferrari, G.S.L.; Ferrari, C.K.B. Exercise Modulation of Total Antioxidant Capacity (TAC): Towards a Molecular Signature of Healthy Aging. Front. Life Sci. 2011, 5, 81-90. [CrossRef]

53. Clopton, D.A.; Saltman, P. Copper-Specific Damage in Human Erythrocytes Exposed to Oxidative Stress. Biol. Trace Elem. Res. 1997, 56, 231-240. [CrossRef]

54. Delangle, P.; Mintz, E. Chelation Therapy in Wilson's Disease: From d-Penicillamine to the Design of Selective Bioinspired Intracellular Cu(i) Chelators. Dalt. Trans. 2012, 41, 6359. [CrossRef] [PubMed]

55. Valko, M.; Morris, H.; Cronin, M.T.D. Metals, Toxicity and Oxidative Stress. Curr. Med. Chem. 2005, 12, 1161-1208. [CrossRef] [PubMed]

56. Pham, A.N.; Xing, G.; Miller, C.J.; Waite, T.D. Fenton-like Copper Redox Chemistry Revisited: Hydrogen Peroxide and Superoxide Mediation of Copper-Catalyzed Oxidant Production. J. Catal. 2013, 301, 54-64. [CrossRef]

57. De Laat, J.; Gallard, H. Catalytic Decomposition of Hydrogen Peroxide by Fe (III) in Homogeneous Aqueous Solution: Mechanism and Kinetic Modeling. Environ. Sci. Technol. 1999, 33, 2726-2732. [CrossRef]

58. Millero, F.J.; Johnson, R.L.; Vega, C.A.; Sharma, V.K.; Sotolongo, S. Effect of Ionic Interactions of the Rates of Reduction of Cu (II) with $\mathrm{H}_{2} \mathrm{O}_{2}$ in Aqueous Solutions. J. Solut. Chem. 1992, 21, 1271-1287. [CrossRef]

59. Moffett, J.W.; Zika, R.G. Reaction Kinetics of Hydrogen Peroxide with Copper and Iron in Seawater. Environ. Sci. Technol. 1987, 21, 804-810. [CrossRef]

60. Jomova, K.; Lawson, M.; Drostinova, L.; Lauro, P.; Poprac, P.; Brezova, V.; Michalik, M.; Lukes, V.; Valko, M. Protective Role of Quercetin against Copper(II)-Induced Oxidative Stress: A Spectroscopic, Theoretical and DNA Damage Study. Food Chem. Toxicol. 2017, 110, 340-350. [CrossRef]

61. Zhang, L.; Qiu, S.; Jiang, G.; Jiang, G.; Tang, R. A Cu ${ }^{\mathrm{II}}$-Based Metal-Organic Framework as an Efficient Photocatalyst for Direct Hydroxylation of Benzene to Phenol in Aqueous Solution. Asian J. Org. Chem. 2018, 7, 165-170. [CrossRef]

62. Stoyanovsky, D.A.; Tyurina, Y.Y.; Shrivastava, I.; Bahar, I.; Tyurin, V.A.; Protchenko, O.; Jadhav, S.; Bolevich, S.B.; Kozlov, A.V.; Vladimirov, Y.A.; et al. Iron Catalysis of Lipid Peroxidation in Ferroptosis: Regulated Enzymatic or Random Free Radical Reaction? Free Radic. Biol. Med. 2019, 133, 153-161. [CrossRef]

63. Cao, J.Y.; Dixon, S.J. Mechanisms of Ferroptosis. Cell. Mol. Life Sci. 2016, 73, 2195-2209. [CrossRef]

64. Repetto, M.; Semprine, J.; Boveris, A. Lipid Peroxidation: Chemical Mechanism, Biological Implications and Analytical Determination. In Lipid Peroxidation; Serra, J., Ed.; Intech: London, UK, 2012.

65. Kim, W.Y.; Jo, E.J.; Eom, J.S.; Mok, J.; Kim, M.H.; Kim, K.U.; Park, H.K.; Lee, M.K.; Lee, K. Combined Vitamin C, Hydrocortisone, and Thiamine Therapy for Patients with Severe Pneumonia Who Were Admitted to the Intensive Care Unit: Propensity ScoreBased Analysis of a before-after Cohort Study. J. Crit. Care 2018, 47, 211-218. [CrossRef] [PubMed]

66. Fowler, A.A.; Truwit, J.D.; Hite, R.D.; Morris, P.E.; Dewilde, C.; Priday, A.; Fisher, B.; Thacker, L.R.; Natarajan, R.; Brophy, D.F.; et al Effect of Vitamin C Infusion on Organ Failure and Biomarkers of Inflammation and Vascular Injury in Patients with Sepsis and Severe Acute Respiratory Failure: The CITRIS-ALI Randomized Clinical Trial. JAMA-J. Am. Med. Assoc. 2019, 322, 1261-1270. [CrossRef] [PubMed]

67. Carr, A.C.; Rosengrave, P.C.; Bayer, S.; Chambers, S.; Mehrtens, J.; Shaw, G.M. Hypovitaminosis C and Vitamin C Deficiency in Critically Ill Patients despite Recommended Enteral and Parenteral Intakes. Crit. Care 2017, 21, 300. [CrossRef] 
68. Berenson, J.R.; Matous, J.; Swift, R.A.; Mapes, R.; Morrison, B.; Yeh, H.S. A Phase I/II Study of Arsenic Trioxide/Bortezomib/Ascorbic Acid Combination Therapy for the Treatment of Relapsed or Refractory Multiple Myeloma. Clin. Cancer Res. 2007, 13, 1762-1768. [CrossRef] [PubMed]

69. Subbarayan, P.R.; Lima, M.; Ardalan, B. Arsenic Trioxide/Ascorbic Acid Therapy in Patients with Refractory Metastatic Colorectal Carcinoma: A Clinical Experience. Acta Oncol. 2007, 46, 557-561. [CrossRef]

70. Bael, T.E.; Peterson, B.L.; Gollob, J.A. Phase II Trial of Arsenic Trioxide and Ascorbic Acid with Temozolomide in Patients with Metastatic Melanoma with or without Central Nervous System Metastases. Melanoma Res. 2008, 18, 147-151. [CrossRef]

71. Fillenbaum, G.G.; Kuchibhatla, M.N.; Hanlon, J.T.; Artz, M.B.; Pieper, C.F.; Schmader, K.E.; Dysken, M.W.; Gray, S.L. Dementia and Alzheimer's Disease in Community-Dwelling Elders Taking Vitamin C and/or Vitamin E. Ann. Pharmacother. 2005, 39, 2009-2014. [CrossRef]

72. Gokce, N.; Keaney, J.F.; Frei, B.; Holbrook, M.; Olesiak, M.; Zachariah, B.J.; Leeuwenburgh, C.; Heinecke, J.W.; Vita, J.A. Long-Term Ascorbic Acid Administration Reverses Endothelial Vasomotor Dysfunction in Patients with Coronary Artery Disease. Circulation 1999, 99, 3234-3240. [CrossRef]

73. Chen, H.; Karne, R.J.; Hall, G.; Campia, U.; Panza, J.A.; Cannon, R.O.; Wang, Y.; Katz, A.; Levine, M.; Quon, M.J. High-Dose Oral Vitamin C Partially Replenishes Vitamin C Levels in Patients with Type 2 Diabetes and Low Vitamin C Levels but Does Not Improve Endothelial Dysfunction or Insulin Resistance. Am. J. Physiol.-Heart Circ. Physiol. 2006, 290, H137-H145. [CrossRef]

74. Carr, A.C. A New Clinical Trial to Test High-Dose Vitamin C in Patients with COVID-19. Crit. Care 2020, 24, 133. [CrossRef]

75. Macan, A.M.; Kraljević, T.G.; Raić-malić, S. Therapeutic Perspective of Vitamin C and Its Derivatives. Antioxidants 2019, 8, 247. [CrossRef] [PubMed]

76. Naidu, K.A. Vitamin C in Human Health and Disease Is Still a Mystery? An Overview. Nutr. J. 2003, 2, 7. [CrossRef] [PubMed]

77. Pham-Huy, L.A.; He, H.; Pham-Huy, C. Free Radicals, Antioxidants in Disease and Health. Int. J. Biomed. Sci. 2008, 4, 89-96. [PubMed]

78. Galaris, D.; Pantopoulos, K. Oxidative Stress and Iron Homeostasis: Mechanistic and Health Aspects. Crit. Rev. Clin. Lab. Sci. 2008, 45, 1-23. [CrossRef] [PubMed]

79. Young, I.S.; Woodside, J.V. Antioxidants in Health and Disease. J. Clin. Pathol. 2001, 54, 176-186. [CrossRef]

80. Rahman, K. Studies on Free Radicals, Antioxidants, and Co-Factors. Clin. Interv. Aging 2007, 2, $219-236$.

81. Buettner, G.R.; Jurkiewicz, B.A. Catalytic Metals, Ascorbate and Free Radicals: Combinations to Avoid. Radiat. Res. 1996, 145, 532-541. [CrossRef]

82. Kontoghiorghe, C.N.; Kolnagou, A.; Kontoghiorghes, G.J. Phytochelators Intended for Clinical Use in Iron Overload, Other Diseases of Iron Imbalance and Free Radical Pathology. Molecules 2015, 20, 20841-20872. [CrossRef]

83. Bielski, B.H.J.; Allen, A.O.; Schwarz, H.A. Mechanism of Disproportionation of Ascorbate Radicals. J. Am. Chem. Soc. 1981, 103, 3516-3518. [CrossRef]

84. Bielski, B.H.J. Chemistry of Ascorbic Acid Radicals. In Ascorbic Acid: Chemistry, Metabolism, and Uses; Seib, P.A., Tolbert, B.M., Eds.; Advances in Chemistry: Washington, DC, USA, 1982; pp. 81-100. ISBN 9780841206328.

85. Halliwell, B.; Gutteridge, J.M.C. The Antioxidants of Human Extracellular Fluids. Arch. Biochem. Biophys. 1990, $280,1-8$. [CrossRef]

86. Koppenol, W.H.; Hider, R.H. Iron and Redox Cycling. Do's and Don'ts. Free Radic. Biol. Med. 2019, 133, 3-10. [CrossRef] [PubMed]

87. Kontoghiorghes, G.J.; Kolnagou, A.; Kontoghiorghe, C.N.; Mourouzidis, L.; Timoshnikov, V.A.; Polyakov, N.E. Trying to Solve the Puzzle of the Interaction of Ascorbic Acid and Iron: Redox, Chelation and Therapeutic Implications. Medicines 2020, 7, 45 [CrossRef] [PubMed]

88. Timoshnikov, V.A.; Kobzeva, T.; Selyutina, O.Y.; Polyakov, N.E.; Kontoghiorghes, G.J. Effective Inhibition of Copper-Catalyzed Production of Hydroxyl Radicals by Deferiprone. J. Biol. Inorg. Chem. 2019, 24, 331-341. [CrossRef] [PubMed]

89. Timoshnikov, V.A.; Kichigina, L.A.; Selyutina, O.Y.; Polyakov, N.E.; Kontoghiorghes, G.J. Antioxidant Activity of Deferasirox and Its Metal Complexes in Model Systems of Oxidative Damage: Comparison with Deferiprone. Molecules 2021, 26, 5064. [CrossRef]

90. Erdem, G.; Öner, C.; Önal, A.M.; Kisakürek, D.; Ögüs, A.Y. Free Radical Mediated Interaction of Ascorbic Acid and Ascorbate/Cu(II) with Viral and Plasmid DNAs. J. Biosci. 1994, 19, 9-17. [CrossRef]

91. Gerster, H. High-Dose Vitamin C: A Risk for Persons with High Iron Stores? Int. J. Vitam. Nutr. Res. 1999, 69, 67-82. [CrossRef]

92. Carr, A.; Frei, B. Does Vitamin C Act as a Pro-Oxidant under Physiological Conditions? FASEB J. 1999, 13, 1007-1024. [CrossRef]

93. Van Gorkom, G.N.Y.; Lookermans, E.L.; Van Elssen, C.H.M.J.; Bos, G.M.J. The Effect of Vitamin C (Ascorbic Acid) in the Treatment of Patients with Cancer: A Systematic Review. Nutrients 2019, 11, 977. [CrossRef]

94. Borst, P. Mega-Dose Vitamin C as Therapy for Human Cancer? Proc. Natl. Acad. Sci. USA 2008, 105, 95. [CrossRef]

95. Hoffer, L.J.; Levine, M.; Assouline, S.; Melnychuk, D.; Padayatty, S.J.; Rosadiuk, K.; Rousseau, C.; Robitaille, L.; Miller, W.H. Phase I Clinical Trial of i.v. Ascorbic Acid in Advanced Malignancy. Ann. Oncol. 2008, 19, 1969-1974. [CrossRef]

96. Frei, B.; Lawson, S. Vitamin C and Cancer Revisited. Proc. Natl. Acad. Sci. USA 2008, 105, 11037-11038. [CrossRef] [PubMed]

97. Singh, N.K.; Kumbhar, A.A.; Pokharel, Y.R.; Yadav, P.N. Anticancer Potency of Copper(II) Complexes of Thiosemicarbazones. J. Inorg. Biochem. 2020, 210, 111134. [CrossRef] [PubMed]

98. Glorieux, C.; Buc Calderon, P. Vitamin C (Ascorbate) and Redox Topics in Cancer. Antioxid. Redox Signal. 2021, 35, 1157-1175. [CrossRef] [PubMed] 
99. Zümreoglu-Karan, B. The Coordination Chemistry of Vitamin C: An Overview. Coord. Chem. Rev. 2006, 250, 2295-2307. [CrossRef]

100. Grillet, L.; Ouerdane, L.; Flis, P.; Hoang, M.T.T.; Isaure, M.P.; Lobinski, R.; Curie, C.; Mari, S. Ascorbate Efflux as a New Strategy for Iron Reduction and Transport in Plants. J. Biol. Chem. 2014, 289, 2515-2525. [CrossRef]

101. Nayak, S.; Dash, A.C. Phenol-Amide Chelates of Iron(III). Kinetics and Mechanism of Reversible Formation of (Diaqua) $(1,3)$ Bis (2-Hydroxybenzamido)Propaneiron(III) and Its Reactions with Thiocyanate, Azide, Imidazole, Sulphur(IV) and Ascorbic Acid in Aqueous Medium. Indian J. Chem.-Sect. A 2003, 42, 2427-2438.

102. Ortega-Castro, J.; Frau, J.; Casasnovas, R.; Fernández, D.; Donoso, J.; Muñoz, F. High- and Low-Spin Fe(III) Complexes of Various AGE Inhibitors. J. Phys. Chem. A 2012, 116, 2961-2971. [CrossRef]

103. Hininger, I.; Waters, R.; Osman, M.; Garrel, C.; Fernholz, K.; Roussel, A.M.; Anderson, R.A. Acute Prooxidant Effects of Vitamin $\mathrm{C}$ in EDTA Chelation Therapy and Long-Term Antioxidant Benefits of Therapy. Free Radic. Biol. Med. 2005, 38, 1565-1570. [CrossRef]

104. Martell, A.E. Ascorbic Acid: Chemistry, Metabolism, and Uses. In Ascorbic Acid: Chemistry, Metabolism, and Uses; Seib, P.A., Tolbert, B.M., Eds.; ACS Publications: Washington, DC, USA, 1982; pp. 153-178. ISBN 780841206328.

105. Kontoghiorghes, G.J.; Kontoghiorghe, C.N. Iron and Chelation in Biochemistry and Medicine: New Approaches to Controlling Iron Metabolism and Treating Related Diseases. Cells 2020, 9, 1456. [CrossRef]

106. Keypour, H.; Silver, J.; Wilson, M.T.; Hamed, M.Y. Studies on the Reactions of Ferric Iron with Ascorbic Acid. A Study of Solution Chemistry Using Mössbauer Spectroscopy and Stopped-Flow Techniques. Inorg. Chim. Acta 1986, 125, 97-106. [CrossRef]

107. Yuan, X.; Pham, A.N.; Xing, G.; Rose, A.L.; Waite, T.D. Effects of PH, Chloride, and Bicarbonate on Cu(I) Oxidation Kinetics at Circumneutral PH. Environ. Sci. Technol. 2012, 46, 1527-1535. [CrossRef]

108. Mahata, S.; Mitra, I.; Mukherjee, S.; Venkata Pera, R.B.; Ghosh, G.K.; Linert, W.; Moi, S.C. Speciation Study of L-Ascorbic Acid and Its Chelated $\mathrm{Cu}(\mathrm{II}) \& \mathrm{Ni}(\mathrm{II})$ Complexes: An Experimental and Theoretical Model of Complex Formation. S. Afr. J. Chem. 2019, 72, 229-236. [CrossRef]

109. Moffett, J.W.; Zika, R.G. Oxidation Kinetics of $\mathrm{Cu}(\mathrm{I})$ in Seawater: Implications for Its Existence in the Marine Environment. Mar Chem. 1983, 13, 239-251. [CrossRef]

110. Hou, X.; Huang, X.; Ai, Z.; Zhao, J.; Zhang, L. Ascorbic Acid/Fe@ $\mathrm{Fe}_{2} \mathrm{O}_{3}$ : A Highly Efficient Combined Fenton Reagent to Remove Organic Contaminants. J. Hazard. Mater. 2016, 310, 170-178. [CrossRef] [PubMed]

111. He, D.Q.; Zhang, Y.J.; Pei, D.N.; Huang, G.X.; Liu, C.; Li, J.; Yu, H.Q. Degradation of Benzoic Acid in an Advanced Oxidation Process: The Effects of Reducing Agents. J. Hazard. Mater. 2020, 382, 121090. [CrossRef] [PubMed]

112. Polyakov, N.E.; Leshina, T.V.; Konovalova, T.A.; Kispert, L.D. Carotenoids as scavengers of free radicals in a fenton reaction: Antioxidants or pro-oxidants? Free Radic. Biol. Med. 2001, 31, 398-404. [CrossRef]

113. Polyakov, N.E.; Leshina, T.V.; Salakhutdinov, N.F.; Konovalova, T.A.; Kispert, L.D. Antioxidant and Redox Properties of Supramolecular Complexes of Carotenoids with $\beta$-Glycyrrhizic Acid. Free Radic. Biol. Med. 2006, 40, 1804-1809. [CrossRef]

114. Salgado, P.; Melin, V.; Contreras, D.; Moreno, Y.; Mansilla, H.D. Fenton Reaction Driven by Iron Ligands. J. Chil. Chem. Soc. 2013, 58, 2096-2101. [CrossRef]

115. Jiang, X.; Zhou, T.; Bai, R.; Xie, Y. Hydroxypyridinone-Based Iron Chelators with Broad-Ranging Biological Activities. J. Med. Chem. 2020, 63, 14470-14501. [CrossRef] [PubMed]

116. Santos, M.A.; Marques, S.M.; Chaves, S. Hydroxypyridinones as "Privileged" Chelating Structures for the Design of Medicinal Drugs. Coord. Chem. Rev. 2012, 256, 240-259. [CrossRef]

117. Telpoukhovskaia, M.A.; Patrick, B.O.; Rodríguez-Rodríguez, C.; Orvig, C. In Silico to in Vitro Screening of Hydroxypyridinones as Acetylcholinesterase Inhibitors. Bioorg. Med. Chem. Lett. 2016, 26, 1624-1628. [CrossRef] [PubMed]

118. Kontoghiorghes, G. The Design of Orally Active Iron Chelators for the Treatment of Thalassaemia. Ph.D. Thesis, University of Essex, Colchester, UK, 1982; pp. 1-243. Available online: https://www.pri.ac.cy/files/KGJ_thesis_1982.pdf (accessed on 22 December 2021).

119. Kontoghiorghes, G.J.; Evans, R.W. Site Specificity of Iron Removal from Transferrin by Alpha-Ketohydroxypyridine Chelators. FEBS Lett. 1985, 189, 141-144. [CrossRef]

120. Kontoghiorghes, G.J. Design, Properties, and Effective Use of the Oral Chelator L1 and Other Alpha-Ketohydroxypyridines in the Treatment of Transfusional Iron Overload in Thalassemia. Ann. N. Y. Acad. Sci. 1990, 612, 339-350. [CrossRef]

121. Kontoghiorghes, G.J. Orally Active Alpha-Ketohydroxypyridine Iron Chelators: Effects on Iron and Other Metal Mobilisations. Acta Haematol. 1987, 78, 212-216. [CrossRef] [PubMed]

122. Kontoghiorghes, G.J. Orally Active Alpha-Ketohydroxypyridine Iron Chelators: Studies in Mice-PubMed. Mol. Pharmacol. 1986, 30, 670-673.

123. Kontoghiorghes, G.J.; Hoffbrand, A.V. Orally Active Alpha-Ketohydroxy Pyridine Iron Chelators Intended for Clinical Use: In Vivo Studies in Rabbits. Br. J. Haematol. 1986, 62, 607-613. [CrossRef]

124. Kontoghiorghes, G.J. The Study of Iron Mobilisation from Transferrin Using Alpha-Ketohydroxy Heteroaromatic Chelators. Biochim. Biophys. Acta 1986, 869, 141-146. [CrossRef]

125. Kontoghiorghes, G.J. Iron Mobilisation from Lactoferrin by Chelators at Physiological PH. BBA-Gen. Subj. 1986, 882, 267-270 [CrossRef]

126. Kontoghiorghes, J.; Chambers, S.; Hoffbrand, A.V. Comparative Study of Iron Mobilization from Haemosiderin, Ferritin and Iron(III) Precipitates by Chelators. Biochem. J. 1987, 241, 87-92. [CrossRef] 
127. Kontoghiorghes, G.J. New Orally Active Alpha-Ketohydroxy Pyridine Chelators for the Treatment of Iron Overload. Birth Defects Orig. Artic. Ser. 1988, 23, 97-103.

128. Celli, J.P.; Spring, B.Q.; Rizvi, I.; Evans, C.L.; Samkoe, K.S.; Verma, S.; Pogue, B.W.; Hasan, T. Imaging and Photodynamic Therapy: Mechanisms, Monitoring, and Optimization. Chem. Rev. 2010, 110, 2795-2838. [CrossRef] [PubMed]

129. Ferrari, S.; Palmerini, E. Adjuvant and Neoadjuvant Combination Chemotherapy for Osteogenic Sarcoma. Curr. Opin. Oncol. 2007, 19, 341-346. [CrossRef] [PubMed]

130. Weiner, L.M. Oxygen Radicals Generation and DNA Scission by Anticancer and Synthetic Quinones. Methods Enzymol. 1994, 233, 92-105. [CrossRef] [PubMed]

131. Bhattacharya, B.; Mukherjee, S. Cancer Therapy Using Antibiotics. J. Cancer Ther. 2015, 6, 849-858. [CrossRef]

132. Ahmad, I.; Ahmed, S.; Anwar, Z.; Sheraz, M.A.; Sikorski, M. Photostability and Photostabilization of Drugs and Drug Products. Int. J. Photoenergy 2016, 2016, 8135608. [CrossRef]

133. Girotti, A.W. Photodynamic Lipid Peroxidation in Biological Systems. Photochem. Photobiol. 1990, 51, 497-509. [CrossRef]

134. Abdel-Kader, M.H. History of Photodynamic Therapy. In Photodynamic Therapy: From Theory to Application; Springer: Berlin/Heidelberg, Germany, 2014; pp. 3-22. ISBN 9783642396298.

135. Štěrba, M.S.; Popelová, O.; Vávrová, A.; Jirkovský, E.; Kovaříková, P.; Geršl, V.; Šimůnek, T.S. Oxidative Stress, Redox Signaling, and Metal Chelation in Anthracycline Cardiotoxicity and Pharmacological Cardioprotection. Antioxid. Redox Signal. 2013, 18, 899-929. [CrossRef]

136. Zhang, Q.; He, J.; Yu, W.; Li, Y.; Liu, Z.; Zhou, B.; Liu, Y. A Promising Anticancer Drug: A Photosensitizer Based on the Porphyrin Skeleton. RSC Med. Chem. 2020, 11, 427-437. [CrossRef]

137. Zhu, H.; Sarkar, S.; Scott, L.; Danelisen, I.; Trush, M.A.; Jia, Z.; Li, Y.R. Doxorubicin Redox Biology: Redox Cycling, Topoisomerase Inhibition, and Oxidative Stress HHS Public Access. React. Oxigen Species 2016, 1, 189-198. [CrossRef]

138. Frankel, E.N. Phenolic Antioxidant. In Lipid Oxidation; Elsevier: Amsterdam, The Netherlands, 2012; pp. $209-258$.

139. Bebbington, D.; Monck, N.J.T.; Gaur, S.; Palmer, A.M.; Benwell, K.; Harvey, V.; Malcolm, C.S.; Porter, R.H.P. 3,5-Disubstituted-4Hydroxyphenyls Linked to 3-Hydroxy-2-Methyl-4(1H)-Pyridinone: Potent Inhibitors of Lipid Peroxidation and Cell Toxicity. J. Med. Chem. 2000, 43, 2779-2782. [CrossRef]

140. Koppenol, W.H.; Stanbury, D.M.; Bounds, P.L. Electrode Potentials of Partially Reduced Oxygen Species, from Dioxygen to Water. Free Radic. Biol. Med. 2010, 49, 317-322. [CrossRef] [PubMed]

141. Kontoghiorghes, G.J.; Kleanthous, M.; Kontoghiorghe, C.N. The History of Deferiprone (L1) and the Paradigm of the Complete Treatment of Iron Overload in Thalassaemia. Mediterr. J. Hematol. Infect. Dis. 2020, 12, e2020011. [CrossRef] [PubMed]

142. Chaves, S.; Piemontese, L.; Hiremathad, A.; Santos, M.A. Hydroxypyridinone Derivatives: A Fascinating Class of Chelators with Therapeutic Applications-An Update. Curr. Med. Chem. 2017, 25, 97-112. [CrossRef] [PubMed]

143. Kontoghiorghes, G.J.; Neocleous, K.; Kolnagou, A. Benefits and Risks of Deferiprone in Iron Overload in Thalassaemia and Other Conditions: Comparison of Epidemiological and Therapeutic Aspects with Deferoxamine. Drug Saf. 2003, 26, 553-584. [CrossRef] [PubMed]

144. Kontoghiorghes, G.; Pattichis, K.; Neocleous, K.; Kolnagou, A. The Design and Development of Deferiprone (L1) and Other Iron Chelators for Clinical Use: Targeting Methods and Application Prospects. Curr. Med. Chem. 2004, 11, 2161-2183. [CrossRef]

145. Kontoghiorghes, G.; Eracleous, E.; Economides, C.; Kolnagou, A. Advances in Iron Overload Therapies. Prospects for Effective Use of Deferiprone (L1), Deferoxamine, the New Experimental Chelators ICL670, GT56-252, L1NAll and Their Combinations. Curr. Med. Chem. 2005, 12, 2663-2681. [CrossRef]

146. Sheppard, L.N.; Kontoghiorghes, G.J. Competition between Deferiprone, Desferrioxamine and Other Chelators for Iron and the Effect of Other Metals. Arzneimittelforschung 1993, 43, 659-663.

147. Kontoghiorghes, G.J.; Jackson, M.J.; Lunec, J. In Vitro Screening of Iron Chelators Using Models of Free Radical Damage. Free Radic. Res. Commun. 1986, 2, 115-124. [CrossRef]

148. Timoshnikov, V.A.; Kobzeva, T.V.; Polyakov, N.E.; Kontoghiorghes, G.J. Inhibition of $\mathrm{Fe}^{2+}$ - and Fe ${ }^{3+}$-Induced Hydroxyl Radical Production by the Iron-Chelating Drug Deferiprone. Free Radic. Biol. Med. 2015, 78, 118-122. [CrossRef]

149. Timoshnikov, V.A.; Kobzeva, T.V.; Polyakov, N.E.; Kontoghiorghes, G.J. Redox interactions of vitamin c and iron: Inhibition of the pro-oxidant activity by deferiprone. Int. J. Mol. Sci. 2020, 21, 3967. [CrossRef]

150. Merkofer, M.; Kissner, R.; Hider, R.C.; Koppenol, W.H. Redox Properties of the Iron Complexes of Orally Active Iron Chelators CP20, CP502, CP509, and ICL670. Helv. Chim. Acta 2004, 87, 3021-3034. [CrossRef]

151. Akrawinthawong, K.; Chaowalit, N.; Chatuparisuth, T.; Siritanaratkul, N. Effectiveness of Deferiprone in Transfusionindependent Beta-Thalassemia/HbE Patients. Hematology 2011, 16, 113-122. [CrossRef] [PubMed]

152. Pashalidis, I.; Kontoghiorghes, G.J. Competition Studies of L1-Deferiprone with Copper and Iron. Possible Implications on Efficacy, Toxicity and New Therapeutic Applications. Transfus. Sci. 2000, 23, 259-261. [CrossRef]

153. Pashalidis, I.; Kontoghiorghes, G.J. Molecular Factors Affecting the Complex Formation between Deferiprone (L1) and Cu(II). Possible Implications on Efficacy and Toxicity. Arzneimittelforschung 2001, 51, 998-1003. [CrossRef]

154. Kontoghiorghe, C.N.; Kontoghiorghes, G.J. Efficacy and Safety of Iron-Chelation Therapy with Deferoxamine, Deferiprone, and Deferasirox for the Treatment of Iron-Loaded Patients with Non-Transfusion-Dependent Thalassemia Syndromes. Drug Des. Devel. Ther. 2016, 10, 465-481. [CrossRef] 
155. Kontoghiorghes, G.J.; Graham Goddard, J.; Bardett, A.N.; Sheppard, L. Pharmacokinetic Studies in Humans with the Oral Iron Chelator 1,2-Dimethyl-3-Hydroxypyrid-4-One. Clin. Pharmacol. Ther. 1990, 48, 255-261. [CrossRef]

156. Levy, M.; Llinas, R. Pilot Safety Trial of Deferiprone in 10 Subjects with Superficial Siderosis. Stroke 2012, 43, 120-124. [CrossRef]

157. Elincx-Benizri, S.; Glik, A.; Merkel, D.; Arad, M.; Freimark, D.; Kozlova, E.; Cabantchik, I.; Hassin-Baer, S. Clinical Experience with Deferiprone Treatment for Friedreich Ataxia. J. Child Neurol. 2016, 31, 1036-1040. [CrossRef]

158. Zou, C.; Liu, X.; Xie, R.; Bao, Y.; Jin, Q.; Jia, X.; Li, L.; Liu, R. Deferiprone Attenuates Inflammation and Myocardial Fibrosis in Diabetic Cardiomyopathy Rats. Biochem. Biophys. Res. Commun. 2017, 486, 930-936. [CrossRef]

159. Liu, J.L.; Fan, Y.G.; Yang, Z.S.; Wang, Z.Y.; Guo, C. Iron and Alzheimer's Disease: From Pathogenesis to Therapeutic Implications. Front. Neurosci. 2018, 12, 217-227. [CrossRef]

160. Kontoghiorghes, G.J.; Efstathiou, A.; Ioannou-Loucaides, S.; Kolnagou, A. Chelators Controlling Metal Metabolism and Toxicity Pathways: Applications in Cancer Prevention, Diagnosis and Treatment. Hemoglobin 2008, 32, 217-227. [CrossRef] [PubMed]

161. Murakami, K.; Yoshino, M. Generation of Reactive Oxygen Species by Hydroxypyridone Compound/Iron Complexes. Redox Rep. 2020, 25, 59-63. [CrossRef] [PubMed]

162. Fiorillo, M.; Brindisi, M.; Sotgia, F.; Lisanti, M.P. Deferiprone (DFP) Targets Cancer Stem Cell (CSC) Propagation by Inhibiting Mitochondrial Metabolism and Inducing ROS Production. Cells 2020, 9, 1529. [CrossRef] [PubMed]

163. Timoshnikov, V.A.; Klimentiev, V.I.; Polyakov, N.E.; Kontoghiorghes, G.J. Photoinduced Transformation of Iron Chelator Deferiprone: Possible Implications in Drug Metabolism and Toxicity. J. Photochem. Photobiol. A Chem. 2014, 289, 14-21. [CrossRef]

164. Alzheimer's Association. 2014 Alzheimer's Disease Facts and Figures. Alzheimer's Dement. 2014, 10, 47-92. [CrossRef]

165. Oddo, S.; Caccamo, A.; Shepherd, J.D.; Murphy, M.P.; Golde, T.E.; Kayed, R.; Metherate, R.; Mattson, M.P.; Akbari, Y.; LaFerla, F.M. Triple-Transgenic Model of Alzheimer's Disease with Plaques and Tangles: Intracellular Abeta and Synaptic Dysfunction. Neuron 2003, 39, 409-421. [CrossRef]

166. Ayton, S.; Lei, P.; Bush, A.I. Metallostasis in Alzheimer's Disease. Free Radic. Biol. Med. 2013, 62, 76-89. [CrossRef]

167. Gazova, Z.; Soukup, O.; Sepsova, V.; Siposova, K.; Drtinova, L.; Jost, P.; Spilovska, K.; Korabecny, J.; Nepovimova, E.; Fedunova, D.; et al. Multi-Target-Directed Therapeutic Potential of 7-Methoxytacrine-Adamantylamine Heterodimers in the Alzheimer's Disease Treatment. Biochim. Biophys. Acta-Mol. Basis Dis. 2017, 1863, 607-619. [CrossRef]

168. Hiremathad, A.; Chand, K.; Tolayan, L.; Rajeshwari; Keri, R.S.; Esteves, A.R.; Cardoso, S.M.; Chaves, S.; Santos, M.A. Hydroxypyridinone-Benzofuran Hybrids with Potential Protective Roles for Alzheimer's Disease Therapy. J. Inorg. Biochem. 2018, 179, 82-96. [CrossRef]

169. Sheng, R.; Tang, L.; Jiang, L.; Hong, L.; Shi, Y.; Zhou, N.; Hu, Y. Novel 1-Phenyl-3-Hydroxy-4-Pyridinone Derivatives as Multifunctional Agents for the Therapy of Alzheimer's Disease. ACS Chem. Neurosci. 2016, 7, 69-81. [CrossRef] [PubMed]

170. Bhowmik, M.; Khanam, R.; Vohora, D. Histamine H3 Receptor Antagonists in Relation to Epilepsy and Neurodegeneration: A Systemic Consideration of Recent Progress and Perspectives. Br. J. Pharmacol. 2012, 167, 1398. [CrossRef] [PubMed]

171. Santos, M.A.; Chand, K.; Chaves, S. Recent Progress in Repositioning Alzheimer's Disease Drugs Based on a Multitarget Strategy. Future Med. Chem. 2016, 8, 2113-2142. [CrossRef] [PubMed]

172. Nunes, A.; Marques, S.M.; Quintanova, C.; Silva, D.F.; Cardoso, S.M.; Chaves, S.; Santos, M.A. Multifunctional Iron-Chelators with Protective Roles against Neurodegenerative Diseases. Dalt. Trans. 2013, 42, 6058-6073. [CrossRef]

173. Telpoukhovskaia, M.A.; Rodríguez-Rodríguez, C.; Cawthray, J.F.; Scott, L.E.; Page, B.D.G.; Alí-Torres, J.; Sodupe, M.; Bailey, G.A.; Patrick, B.O.; Orvig, C. 3-Hydroxy-4-Pyridinone Derivatives as Metal Ion and Amyloid Binding Agents. Metallomics 2014, 6 , 249-262. [CrossRef] [PubMed]

174. Dikalov, S.; Alov, P.; Rangelova, D. Role of Iron Ion Chelation by Quinones in Their Reduction, Oh-Radical Generation, and Lipid Peroxidation. Biochem. Biophys. Res. Commun. 1993, 195, 113-119. [CrossRef] [PubMed]

175. Menasche, P.; Antebi, H.; Alcindor, L.G.; Teiger, E.; Perez, G.; Giudicelli, Y.; Nordmann, R.; Piwnica, A. Iron Chelation by Deferoxamine Inhibits Lipid Peroxidation during Cardiopulmonary Bypass in Humans. Circulation 1990, 82, $390-396$.

176. Yoshida, Y.; Furuta, S.; Niki, E. Effects of Metal Chelating Agents on the Oxidation of Lipids Induced by Copper and Iron. Biochim. Biophys. Acta (BBA)/Lipids Lipid Metab. 1993, 1210, 81-88. [CrossRef]

177. Alegría, A.E.; Santiago, G. Structural and Hydrophilicity Requirements in Quinone-Induced Lipid Peroxidation of Phosphatidylcholine Vesicles. Toxicol. Environ. Chem. 1998, 65, 1-4. [CrossRef]

178. Markova, I.D.; Polyakov, N.E.; Selyutina, O.Y.; Fedenok, L.G.; Fedotov, K.Y.; Slepneva, I.A.; Leshina, T.V.; Pokrovsky, A.G.; Vasilieva, N.V.; Weiner, L.M. Light-Stimulated Generation of Free Radicals by Quinones-Chelators. Z. Phys. Chem. 2017, 231, 369-389. [CrossRef]

179. Miura, T.; Muraoka, S.; Ogiso, T. Lipid Peroxidation of Rat Erythrocyte Membrane Induced by Adriamycin-Fe ${ }^{3+}$. Pharmacol. Toxicol. 1991, 69, 296-300. [CrossRef]

180. Polyakov, N.; Leshina, T.; Fedenok, L.; Slepneva, I.; Kirilyuk, I.; Furso, J.; Olchawa, M.; Sarna, T.; Elas, M.; Bilkis, I.; et al. Redox-Active Quinone Chelators: Properties, Mechanisms of Action, Cell Delivery, and Cell Toxicity. Antioxid. Redox Signal. 2018, 28, 1394-1403. [CrossRef] [PubMed]

181. Powis, G. Free Radical Formation by Antitumor Quinones. Free Radic. Biol. Med. 1989, 6, 63-101. [CrossRef]

182. Hopkins, R.Z. Superoxide in Biology and Medicine: An Overview. React. Oxig. Species 2016, 1, 99-109. [CrossRef]

183. Thomas, C.E.; Aust, S.D. Release of Iron from Ferritin by Cardiotoxic Anthracycline Antibiotics. Arch. Biochem. Biophys. 1986, 248, 684-689. [CrossRef] 
184. Kwok, J.C.; Richardson, D.R. Anthracyclines Induce Accumulation of Iron in Ferritin in Myocardial and Neoplastic Cells: Inhibition of the Ferritin Iron Mobilization Pathway. Mol. Pharmacol. 2003, 63, 849-861. [CrossRef]

185. Myers, C.E.; Mcguire, W.P.; Liss, R.H.; Ifrim, I.; Grotzinger, K.; Young, R.C. Adriamycin: The Role of Lipid Peroxidation in Cardiac Toxicity and Tumor Response. Science 1977, 197, 165-167. [CrossRef] [PubMed]

186. Hrelia, S.; Fiorentini, D.; Maraldi, T.; Angeloni, C.; Bordoni, A.; Biagi, P.L.; Hakim, G. Doxorubicin Induces Early Lipid Peroxidation Associated with Changes in Glucose Transport in Cultured Cardiomyocytes. Biochim. Biophys. Acta-Biomembr. 2002, 1567, 150-156. [CrossRef]

187. Oleinick, N.L.; Morris, R.L.; Belichenko, I. The Role of Apoptosis in Response to Photodynamic Therapy: What, Where, Why, and How. Photochem. Photobiol. Sci. 2002, 1, 1-21. [CrossRef]

188. MacCormack, M.A. Photodynamic Therapy. Adv. Dermatol. 2006, 22, 219-258. [CrossRef]

189. Keyal, U.; Bhatta, A.K.; Zhang, G.; Wang, X.L. Present and Future Perspectives of Photodynamic Therapy for Cutaneous Squamous Cell Carcinoma. J. Am. Acad. Dermatol. 2019, 80, 765-773. [CrossRef]

190. Shafirstein, G.; Bellnier, D.; Oakley, E.; Hamilton, S.; Potasek, M.; Beeson, K.; Parilov, E. Interstitial Photodynamic Therapy-A Focused Review. Cancers 2017, 9, 12. [CrossRef] [PubMed]

191. Chakravarty, A.R.; Roy, M. Photoactivated DNA Cleavage and Anticancer Activity of 3D Metal Complexes. In Progress in Inorganic Chemistry; Karlin, K.D., Ed.; John Wiley and Sons Inc.: Hoboken, NJ, USA, 2011; Volume 57, pp. 119-202.

192. Garai, A.; Pant, I.; Bhattacharyya, A.; Kondaiah, P.; Chakravarty, A.R. Mitochondria-Targeted Anticancer Activity of BODIPYAppended Iron(III) Catecholates in Red Light. ChemistrySelect 2017, 2, 11686-11692. [CrossRef]

193. Devi, L.R.; Raza, M.K.; Musib, D.; Ramu, V.; Devi, J.; Roy, M. Nucleus Targeting Anthraquinone-Based Copper (II) Complexes as the Potent PDT Agents: Synthesis, Photo-Physical and Theoretical Evaluation. Inorg. Chim. Acta 2020, 500, 119208. [CrossRef]

194. Hudson, L.; Rashdan, E.; Bonn, C.A.; Chavan, B.; Rawlings, D.; Birch-Machin, M.A. Individual and Combined Effects of the Infrared, Visible, and Ultraviolet Light Components of Solar Radiation on Damage Biomarkers in Human Skin Cells. FASEB J. 2020, 34, 3874-3883. [CrossRef] [PubMed]

195. Jabłońska-Trypuć, A.; Świderski, G.; Krętowski, R.; Lewandowski, W. Newly Synthesized Doxorubicin Complexes with Selected Metals-Synthesis, Structure and Anti-Breast Cancer Activity. Molecules 2017, 22, 1106. [CrossRef] [PubMed]

196. Feng, M.; Yang, Y.; He, P.; Fang, Y. Spectroscopic Studies of Copper(II) and Iron(II) Complexes of Adriamycin. Spectrochim. Acta-Part A Mol. Biomol. Spectrosc. 2000, 56, 581-587. [CrossRef]

197. Rahimipour, S.; Gescheidt, G.; Bilkis, I.; Fridkin, M.; Weiner, L. Towards the Efficiency of Pharmacologically Active Quinoid Compounds: Electron Transfer and Formation of Reactive Oxygen Species. Appl. Magn. Reson. 2010, 37, 629-648. [CrossRef]

198. Roy, S.; Mondal, P.; Sengupta, P.S.; Dhak, D.; Santra, R.C.; Das, S.; Guin, P.S. Spectroscopic, Computational and Electrochemical Studies on the Formation of the Copper Complex of 1-Amino-4-Hydroxy-9,10-Anthraquinone and Effect of It on Superoxide Formation by NADH Dehydrogenase. Dalt. Trans. 2015, 44, 5428-5440. [CrossRef]

199. Silveira-Dorta, G.; Monzón, D.M.; Crisóstomo, F.P.; Martín, T.; Martín, V.S.; Carrillo, R. Oxidation with Air by Ascorbate-Driven Quinone Redox Cycling. Chem. Commun. 2015, 51, 7027-7030. [CrossRef]

200. Verrax, J.; Beck, R.; Dejeans, N.; Glorieux, C.; Sid, B.; Pedrosa, R.C.; Benites, J.; Vasquez, D.; Valderrama, J.A.; Buc Calderon, P. Redox-Active Quinones and Ascorbate: An Innovative Cancer Therapy That Exploits the Vulnerability of Cancer Cells to Oxidative Stress. Anticancer Agents Med. Chem. 2011, 11, 213-221. [CrossRef]

201. Taper, H.S. Altered Deoxyribonuclease Activity in Cancer Cells and Its Role in Non Toxic Adjuvant Cancer Therapy with Mixed Vitamins C and K3. Anticancer Res. 2008, 28, 2727-2732. [PubMed]

202. Pfau, C.J. The Thiosemicarbazones. In Handbook of Experimental Pharmacology; Springer: Berlin/Heidelberg, Germany, 1982; pp. 147-204.

203. Pavan, F.R.; Maia, P.I.D.S.; Leite, S.R.; Deflon, V.M.; Batista, A.A.; Sato, D.N.; Franzblau, S.G.; Leite, C.Q. Thiosemicarbazones, semicarbazones, dithiocarbazates and hydrazide/hydrazones: Anti-Mycobacterium tuberculosis activity and cytotoxicity. Eur. J. Med. Chem. 2010, 45, 1898-1905. [CrossRef] [PubMed]

204. Kizilcikli, I.; Kurt, Y.D.; Akkurt, B.; Genel, A.Y.; Birteksöz, S.; Ötük, G.; Ülküseven, B. Antimicrobial Activity of a Series of Thiosemicarbazones and Their Zn II and PdII Complexes. Folia Microbiol. 2007, 52, 15-25. [CrossRef] [PubMed]

205. Matsa, R.; Makam, P.; Kaushik, M.; Hoti, S.L.; Kannan, T. Thiosemicarbazone Derivatives: Design, Synthesis and in Vitro Antimalarial Activity Studies. Eur. J. Pharm. Sci. 2019, 137, 104986. [CrossRef]

206. Mannargudi, M.B.; Deb, S. Clinical Pharmacology and Clinical Trials of Ribonucleotide Reductase Inhibitors: Is It a Viable Cancer Therapy? J. Cancer Res. Clin. Oncol. 2017, 143, 1499-1529. [CrossRef]

207. Kunos, C.A.; Chu, E.; Beumer, J.H.; Sznol, M.; Ivy, S.P. Phase I Trial of Daily Triapine in Combination with Cisplatin Chemotherapy for Advanced-Stage Malignancies. Cancer Chemother. Pharmacol. 2017, 79, 201-207. [CrossRef]

208. Kunos, C.A.; Sherertz, T.M. Long-Term Disease Control with Triapine-Based Radiochemotherapy for Patients with Stage IB2-IIIB Cervical Cancer. Front. Oncol. 2014, 4, 184. [CrossRef]

209. Zeidner, J.F.; Karp, J.E.; Blackford, A.L.; Smith, B.D.; Gojo, I.; Gore, S.D.; Levis, M.J.; Carraway, H.E.; Greer, J.M.; Percy Ivy, S.; et al. A Phase II Trial of Sequential Ribonucleotide Reductase Inhibition in Aggressive Myeloproliferative Neoplasms. Haematologica 2014, 99, 672-678. [CrossRef] 
210. Mortazavi, A.; Ling, Y.; Martin, L.K.; Wei, L.; Phelps, M.A.; Liu, Z.; Harper, E.J.; Ivy, S.P.; Wu, X.; Zhou, B.-S.; et al. A Phase I Study of Prolonged Infusion of Triapine in Combination with Fixed Dose Rate Gemcitabine in Patients with Advanced Solid Tumors. Investig. New Drugs 2013, 31, 685-695. [CrossRef]

211. Yu, Y.; Kalinowski, D.S.; Kovacevic, Z.; Siafakas, A.R.; Jansson, P.J.; Stefani, C.; Lovejoy, D.B.; Sharpe, P.C.; Bernhardt, P.V.; Richardson, D.R. Thiosemicarbazones from the Old to New: Iron Chelators That Are More than Just Ribonucleotide Reductase Inhibitors. J. Med. Chem. 2009, 52, 5271-5294. [CrossRef]

212. Thelander, L.; Gräslund, A. Mechanism of Inhibition of Mammalian Ribonucleotide Reductase by the Iron Chelate of 1Formylisoquinoline Thiosemicarbazone. Destruction of the Tyrosine Free Radical of the Enzyme in an Oxygen-Requiring Reaction-PubMed. J. Biol. Chem. 1983, 258, 4063-4066. [CrossRef]

213. Richardson, D.R.; Sharpe, P.C.; Lovejoy, D.B.; Senaratne, D.; Kalinowski, D.S.; Islam, M.; Bernhardt, P.V. Dipyridyl Thiosemicarbazone Chelators with Potent and Selective Antitumor Activity Form Iron Complexes with Redox Activity. J. Med. Chem. 2006, 49, 6510-6521. [CrossRef] [PubMed]

214. Kalinowski, D.S.; Richardson, D.R. The Evolution of Iron Chelators for the Treatment of Iron Overload Disease and Cancer. Pharmacol. Rev. 2005, 57, 547-583. [CrossRef] [PubMed]

215. Kalinowski, D.S.; Quach, P.; Richardson, D.R. Thiosemicarbazones: The New Wave in Cancer Treatment. Future Med. Chem. 2009, 1, 1143-1151. [CrossRef] [PubMed]

216. Malarz, K.; Mrozek-Wilczkiewicz, A.; Serda, M.; Rejmund, M.; Polanski, J.; Musiol, R. The Role of Oxidative Stress in Activity of Anticancer Thiosemicarbazones. Oncotarget 2018, 9, 17689-17710. [CrossRef] [PubMed]

217. Richardson, D.R.; Kalinowski, D.S.; Richardson, V.; Sharpe, P.C.; Lovejoy, D.B.; Islam, M.; Bernhardt, P.V. 2-Acetylpyridine Thiosemicarbazones Are Potent Iron Chelators and Antiproliferative Agents: Redox Activity, Iron Complexation and Characterization of Their Antitumor Activity. J. Med. Chem. 2009, 52, 1459-1470. [CrossRef] [PubMed]

218. Kalinowski, D.S.; Yu, Y.; Sharpe, P.C.; Islam, M.; Liao, Y.T.; Lovejoy, D.B.; Kumar, N.; Bernhardt, P.V.; Richardson, D.R. Design, Synthesis, and Characterization of Novel Iron Chelators: Structure-Activity Relationships of the 2-Benzoylpyridine Thiosemicarbazone Series and Their 3-Nitrobenzoyl Analogues as Potent Antitumor Agents. J. Med. Chem. 2007, 50, 3716-3729. [CrossRef]

219. Heffeter, P.; Pape, V.F.S.; Enyedy, É.A.; Keppler, B.K.; Szakacs, G.; Kowol, C.R. Anticancer Thiosemicarbazones: Chemical Properties, Interaction with Iron Metabolism, and Resistance Development. Antioxid. Redox Signal. 2019, 30, 1062-1082. [CrossRef]

220. Hasinoff, B.B.; Patel, D. The Iron Chelator Dp44mT Does Not Protect Myocytes against Doxorubicin. J. Inorg. Biochem. 2009, 103, 1093-1101. [CrossRef]

221. Gonzálvez, M.A.; Algarra, A.G.; Basallote, M.G.; Bernhardt, P.V.; Fernández-Trujillo, M.J.; Martínez, M. Proton-Assisted Air Oxidation Mechanisms of Iron(Ii) Bis-Thiosemicarbazone Complexes at Physiological PH: A Kinetico-Mechanistic Study. Dalt. Trans. 2019, 48, 16578-16587. [CrossRef]

222. Jansson, P.J.; Hawkins, C.L.; Lovejoy, D.B.; Richardson, D.R. The Iron Complex of Dp44mT Is Redox-Active and Induces Hydroxyl Radical Formation: An EPR Study. J. Inorg. Biochem. 2010, 104, 1224-1228. [CrossRef] [PubMed]

223. Stacy, A.E.; Palanimuthu, D.; Bernhardt, P.V.; Kalinowski, D.S.; Jansson, P.J.; Richardson, D.R. Zinc(II)-Thiosemicarbazone Complexes Are Localized to the Lysosomal Compartment Where They Transmetallate with Copper Ions to Induce Cytotoxicity. J. Med. Chem. 2016, 59, 4965-4984. [CrossRef] [PubMed]

224. Gutierrez, E.M.; Seebacher, N.A.; Arzuman, L.; Kovacevic, Z.; Lane, D.J.R.; Richardson, V.; Merlot, A.M.; Lok, H.; Kalinowski, D.S.; Sahni, S.; et al. Lysosomal Membrane Stability Plays a Major Role in the Cytotoxic Activity of the Anti-Proliferative Agent, Di-2-Pyridylketone 4,4-Dimethyl-3-Thiosemicarbazone (Dp44mT). Biochim. Biophys. Acta-Mol. Cell Res. 2016, 1863, $1665-1681$. [CrossRef] [PubMed]

225. Barbosa, I.R.; Pinheiro, I.D.S.; Dos Santos, A.D.L.; Echevarria, A.; Goulart, C.M.; Guedes, G.P.; Da Costa, N.A.; Silva, B.M.D.O.E.; Riger, C.J.; Neves, A.P. Synthesis of copper(II) and zinc(II) complexes with chalcone-thiosemicarbazone hybrid ligands: X-ray crystallography, spectroscopy and yeast activity. Transit. Met. Chem. 2018, 43, 739-751. [CrossRef]

226. Ohui, K.; Stepanenko, I.; Besleaga, I.; Babak, M.V.; Stafi, R.; Darvasiova, D.; Giester, G.; Pósa, V.; Enyedy, E.A.; Vegh, D.; et al. Triapine Derivatives Act as Copper Delivery Vehicles to Induce Deadly Metal Overload in Cancer Cells. Biomolecules 2020, 10, 1336. [CrossRef]

227. Santoro, A.; Vileno, B.; Palacios, Ò.; Peris-Díaz, M.D.; Riegel, G.; Gaiddon, C.; Kręzel, A.; Faller, P. Reactivity of Cu(II)-, Zn(II)- and Fe(II)-Thiosemicarbazone Complexes with Glutathione and Metallothionein: From Stability to Dissociation to Transmetallation. Metallomics 2019, 11, 994-1004. [CrossRef]

228. Chen, G.; Niu, C.; Yi, J.; Sun, L.; Cao, H.; Fang, Y.; Jin, T.; Li, Y.; Lou, C.; Kang, J.; et al. Novel Triapine Derivative Induces Copper-Dependent Cell Death in Hematopoietic Cancers. J. Med. Chem. 2019, 62, 3107-3121. [CrossRef]

229. Kowol, C.R.; Heffeter, P.; Miklos, W.; Gille, L.; Trondl, R.; Cappellacci, L.; Berger, W.; Keppler, B.K. Mechanisms Underlying Reductant-Induced Reactive Oxygen Species Formation by Anticancer Copper(II) Compounds. J. Biol. Inorg. Chem. 2012, 17, 409-423. [CrossRef] 
230. Kolesar, J.; Brundage, R.C.; Pomplun, M.; Alberti, D.; Holen, K.; Traynor, A.; Ivy, P.; Wilding, G. Population Pharmacokinetics of 3-Aminopyridine-2-Carboxaldehyde Thiosemicarbazone (Triapine $\left.{ }^{\circledR}\right)$ in Cancer Patients. Cancer Chemother. Pharmacol. 2011, 67, 393-400. [CrossRef]

231. Pitucha, M.; Korga-Plewko, A.; Czylkowska, A.; Rogalewicz, B.; Drozd, M.; Iwan, M.; Kubik, J.; Humeniuk, E.; Adamczuk, G.; Karczmarzyk, Z.; et al. Influence of Complexation of Thiosemicarbazone Derivatives with Cu (II) Ions on Their Antitumor Activity against Melanoma Cells. Int. J. Mol. Sci. 2021, 22, 3104. [CrossRef] 